\title{
A Description of the Imperial Bacteriological Laboratory, Muktesar: its Work and Products
}

BY

Major J. D. E. HOLMES, M.A., D.Sc., M.R.C.V.S.

Imperial Bacteriologist

$619-093$

CALCU'T'TA

SUPERINTENDENT GOVERNMEN'C PIIN'TING: INDIA 1913

Price 8 annas or $9 d$. 


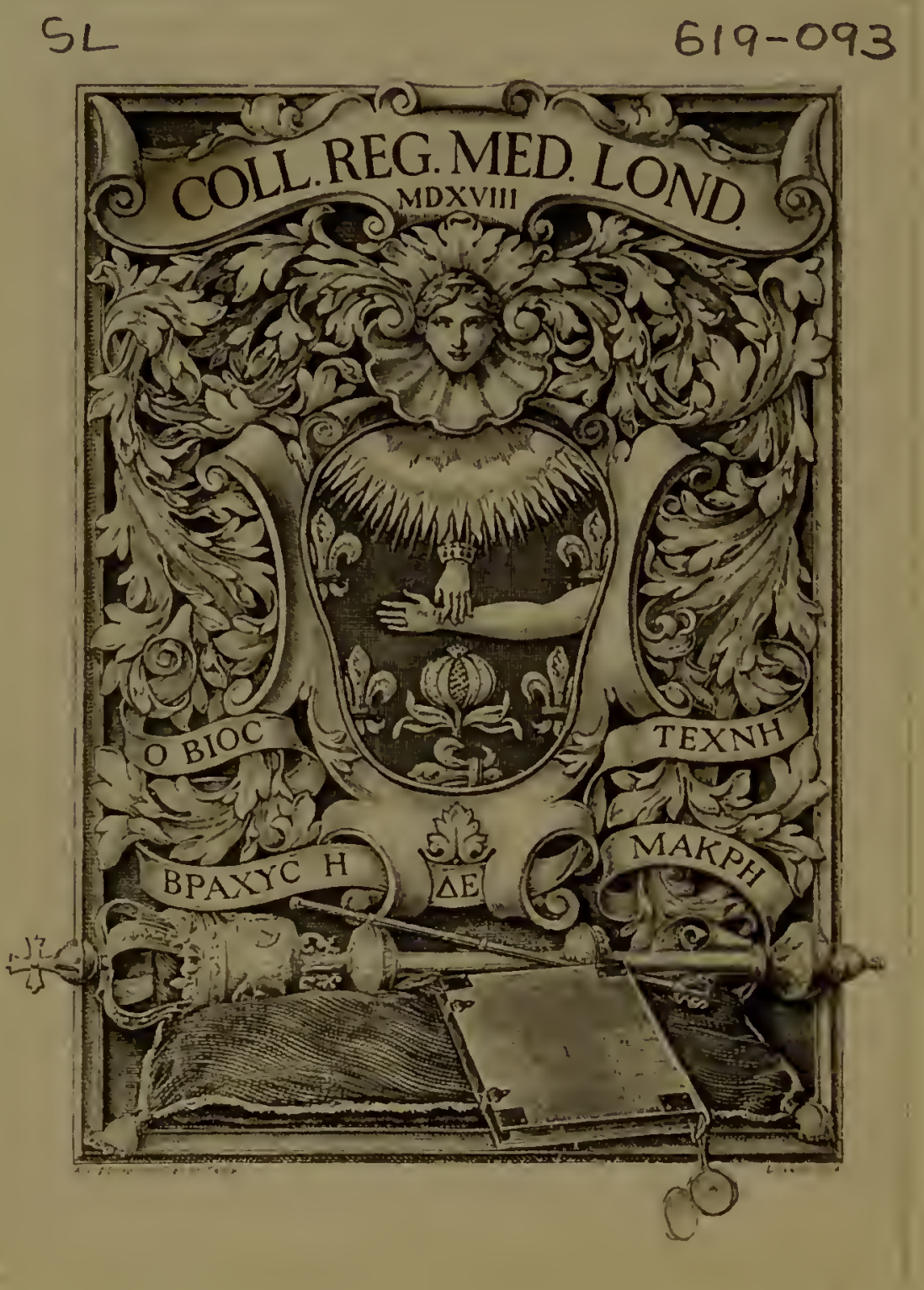





\title{
A Description of the Imperial Bacteriological Laboratory, Muktesar: its Work and Products
}

\author{
BY \\ MAJOR J. D. E. HOLMES, M.A., D.Sc., M.R.C.V.S. \\ Imperial Bacteriologist
}


$b_{19}-\operatorname{oq} 3$

23is 


\section{CONTENTS}

\section{CHAPTER 1.}

A Short History of the Laboratory

\section{CHAPTER II}

A Description of the Laboratory Site and Buildings

CHAPTER III.

The Research Work and Publications of the Laboratory . • . 12

\section{CHAPTER IV.}

The Practical Application of Serums and Vaccines.

\section{CHAPTER V.}

The Products of the Laboratory. 
$$
\text { . }
$$

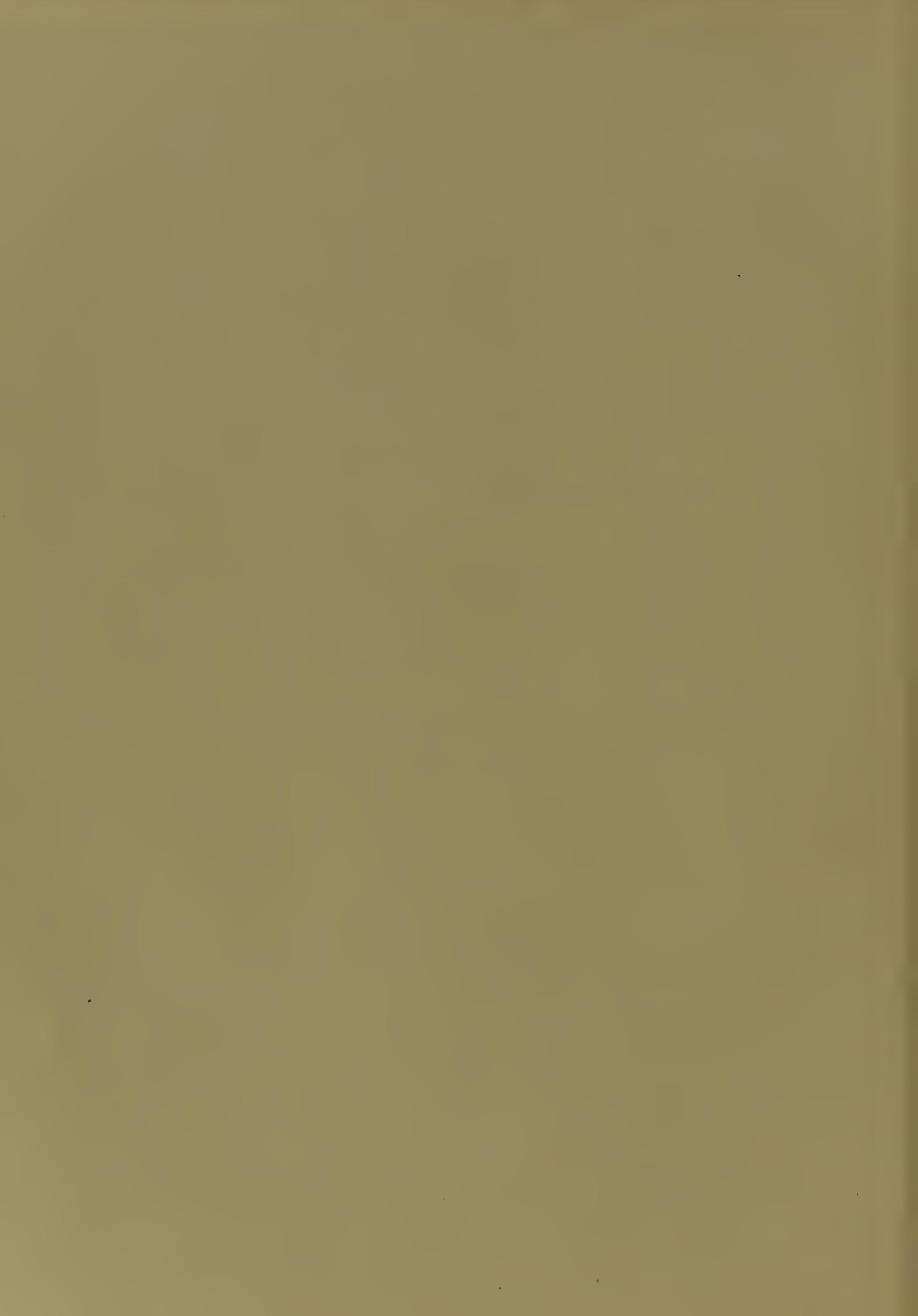




\section{A DESCRIPTION OF THE}

\section{Imperial Bacteriological Laboratory, Muktesar : its Work and Products.}

\section{CHAPTER I.}

\section{A Short History of the Laboratory.}

In 1890 , the first step was taken towards providing facilities for the investigation of the diseases of stock in India. Dr. Lingard was appointed as Imperial Bacteriologist in connection with the Laboratory at the College of Science, Poona. His duties were thus defined.

"To investigate diseases of domesticated animals in all Provinces in India and to ascertain, as far as possible, by biological research both in the Laboratory and, when necessar $y$, at the place of outbreak, the means for preventing and curing such diseases."

For some years, Dr. Lingard worked in the Poona Laboratory mainly on the investigation of Surra in horses. He found, however, that the climate of the plains rendered laboratory research work extremely diffcult and was also little suitable for the manufacture and preservation of vaccines and serums. Consequently, in 1893, it was decided to remove the Laboratory to a suitable site in the Hills, and Muktesar was selected for this purpose.

In 1895 , the Laboratory main building (part of which was used by Dr. Lingard as his residential quarters), a post-mortem house, two onthouses, one cattle shed, a bungalow for the Assistant Bacteriologist and an out-Kral for cattle were completed. The staff consisted of the Tmperial Bacteriologist, Assistant Bacteriologist, one native laboratory assistant, three clerks, one artist and some menials. At this time the investigation of Rinderpest and measures of prophylaxis were taken up and in the following year Professor Koch, at the request of the Government of India, visited Muktesar and demonstrated his bile method of inoculation against Rinderpest. During the following three year's Rinderpest, and the methods of preparing a potent antiserum, were 
further investigated. Two more cattle sheds, a sterilising house, suow well and cold room were added to the buildings.

In 1898, Dr. Lingard was compelled to return to England on sick leave for two years. During this time Major Leonard Rogers held charge of the Laboratory and continued the experiments on Rinderpest antisermm.

In 1899, a fire broke ont in the western end of the Laboratory and the whole bnilding was completely burnt down. The reconstruction of the Laboratory was at once commenced. A water supply scheme was taken in liand and also sanction was obtained for the establishment of a Branch Laboratory at Bareilly, for the purpose of carrying out certain investigations during the winter months of each year.

A potent Rinderpest Serum having been prepared and its application in outbreals of the disease having met with success, a large and increased demand for the serum arose. To provide facilities for the preparation of a sufficient supply of the serum, more cattle sheds and out-Kraals were built, the stafi was also increased and more land was taken up for the accommodation of cattle and providing fodder.

In 1898, Mr. Kricbel was appointed Head Laboratory Assistant and posts for two Veterinary Assistants and a Farm Jamadar were sanctioned.

From 1901-1904, the preparation of antiserums for Anthrax and Hremorrhagic Septicemia, of Black Quarter Vaccine, and of Mallein were added to the list of work. Further accommodation was provided for this increase of work, a second European Laboratory Assistant was engaged, and other additions made to the staff. Oil engines and large Centrifuges were installed and the gas and water pumping plaut increased.

In the following years the demand for the products of the Laboratory rapidly increased and further accommodation had to be provided for the serum-preparing animals.

Three small out-Laboratories for Anthrax, Black Quarter and Glanders were built and, at a later date, another wing was added to the main building.

A course of instruction in Tropical Veterinary diseases and in serum therapeutics was commenced for officers of the Army and Civil Veterinary Department. A Bungalow for their accommodation was built. Each month a class of about six Native Veterinary Gradnates was instructed in the methods of serum injection and in the practical application of serums and vaccines. Quarters were provided for these men.

An Institute and tennis grounds for the recreation of the members of the staff were constructed and a Dispensary and Hospital in charge of a Snb-Assistant Surgeon were provided. 
The Meteorological Observatory shed was equipped with extra instruments and converted into a second class Departmental Observatory.

At the present time the chief buildings in Muktesar are:-

(1) Main Laboratory buildings.

(2) Three ont-Laboratories for Anthrax, Charbon Symptomatique and Nallein preparation.

(3) Sterilising House.

(4) Centrifuge and Serum Rooms.

(5) Serum filling and bottling house.

(6) Packing House and Carpenters' Shop.

(7) Bottle Washing Room.

(8) Two Cold Storage Rooms.

(9) Girain and Oil Godowns.

(10) Farm Manager's Office.

(11) Power House and Work Shop.

(12) Gas Honse.

(13) Water Pumping House.

(14) Small Animals' House.

(15) Three Stables to accommodate 25 horses.

(16) Dog Kennels.

(17) Eleven sherls to accommodate 400 cattle.

(18) Two Post-Mortem Houses and Incinerator.

(19) Five Operating Sheds.

(20) Six ont-Kirals to accommodate 300 cattle.

(21) The Institute.

(22) The Dispensary, Hospital and Segregation Ward.

(23) Dharmsala and Shops.

(24) Post and Telegraph Office.

(25) Visitors' Bungalow.

(26) Public Works Department Inspection Bungalow.

(27) School for the education of the children of the Native Staff.

Residences for the permanent staft which in 1912 consisted of :-

Imperial Bacteriologist.-Major J. D. F. Holmes.

Assistant Bacteriologist.-Mr. H. E. C'ross.

Physiological Chemisl.-Dr. P. Hartley.

Head European Laboralory Assistanl.-Mr. M. Kriebel.

2nd European Laboratory Assistant.-Mr. D. Keiller.

3rd European Laboratory Assistant.-Mr. G. P. Goffi.

Eilectrician.-Mr. P. W. C'rawshaw. 
Farm Manager.-Mr. MeGinn.

Senior Velerinary Inspeclor.-Khan Sahib Wazir Mohamed.

Senior Velerinary Inspeelor.-Mr. D'Monte.

Junior Veterinary Inspeelor.-Babu Abdul Ghani.

Junior Velerinary Inspeelor.- Mr. D Costa.

Head Clerk.-Pundit Krishna Nand.

Aceountant.--Rai Sahib Pundit Nitya Nand.

Suv́-Assislanl Surgeon.-Pundit Ajudhia Parshad Misir.

Artist and Pholographer.-Babn Duni Chand.

2nd. Clerk.-Pundit Ram Datt.

Munshi-Munshi Azimushan Khan.

Despalcher and Meleorological Observer-Lala Parsi Sah.

Assistant Engineman-Mangal Mistri.

Store-keeper-Babu Godar Mal Lamba.

Librarian-Iala B. C. Gupta.

Farm Overseer--Babu Sher Singh Rana.

Farm Jamadar-Narain Singh.

Gorloun Keeper-Pundit Gopal Dutt.

Ist Native Laboralory Assistan-Babu Ajoon Sen.

2nd Nalive Laboralory Assislanl-Babu J. II. Dass.

3rd Nalive Laboralory Assislanl-Babu Prem Dass.

Compounder-Babu Nathi Singh.

10 Dressers, 26 Menials, 10 Laboratory Bearers, 2 Packers and Carpenters and 350 coolies and cattlemen.

List of Officers who have held appointmenls on the Muktesar Laboralory.

$25 t h$ Augusl, 1890-Dr. Lingard appointed.

1893-Mr. Bamber appointed Clinical Assistant to the Imperial Bacteriologist.

1898-Dr. Lingard absent on siek leave from November 1898 to January 1900.

Dr. Rogers appointed from November 1898 to January 1900.

101h April, 1898-Dr. Stephens arrived. Resigned 23rd June 1898, being relieved by Lientenant Walker as Assistant Baetcriologist.

1898-Mr. Kriebel appointed Head Laboratory Assistant.

1901-02-Lieutenant Holmes relieved Lieutenant Wallier. Mr. Keiller appointed 2nd Laboratory Assistant.

1904-05-Captain Holmes went home on deputation. Mr. Montgomery relieving him as Assistant Baeteriologist. 
1905-06-Mr. Martin relieved Mr. Montgomery as Assistant Bacteriologist. Mr. Cross appointed 2nd Assistant Bacteriologist.

Mr. Goffi 3rd Laboratory Assistant.

1907-08-Dr. Lingard retired and Captain Holmes appointed Imperial Bacteriologist. AIr. Cross relieved Mr. Martin as Assistant Bacteriologist. Mr. Branford attached to Laboratory for training.

1909-Dr. Hartley appointed Physiological Chemist. Mr. Cattell attached to the Laboratory for training.

February, 1910-Major Holmes went home on leave and Major Baldrey officiated.

November, 1910-Major Holmes returned from leave and took over charge from Major Baldrey.

1912-Mr. Crawshaw appointed Electrician. Mr. MeGinn appointed Farm Mamager. Mr. Mobbs appninted Laboratory Assistant.

List of officers who have attended a course of instruction or siudied, at the Laboratory.

\begin{tabular}{|c|c|c|c|c|c|}
\hline Name. & \multicolumn{3}{|c|}{ Date of arrival. } & Date of departure. & $\begin{array}{l}\text { Periud of } \\
\text { culuse. }\end{array}$ \\
\hline \multicolumn{6}{|l|}{$1904-1905$} \\
\hline Mrr. K. Hewlett & $A_{p}$ ril & . & • & 28th June, 1904 & 2 montls. \\
\hline $\begin{array}{l}\text { Captain H. M. Dur- } \\
\text { rant. }\end{array}$ & June & . & - & 31st July, 1904 & do. " \\
\hline $\begin{array}{l}\text { Lieutenant S. F. G. } \\
\text { Pallin. }\end{array}$ & August . & . & . & 30th September, 1904 & do. \\
\hline $\begin{array}{l}\text { Lieutenant A. E. Dal- } \\
\text { gleish. }\end{array}$ & August . & . & . & 30th September, 1904 & do. \\
\hline \multicolumn{6}{|l|}{$1905-1906$} \\
\hline Licutenant H. Glasse & May 30 th & . & & 3lst July, 190.5 & 2 months \\
\hline Lieutenant C. E. Steel & May 30th & . & • & 31st July, 1905 & do:", \\
\hline $\begin{array}{l}\text { Lieutenant } \quad \text { F. } \\
\text { O'Ros.ke. }\end{array}$ & 2nd August & . & • & 30 th September, 1905 & do. \\
\hline $\begin{array}{l}\text { Lieutenant N. d'E. } \\
\text { Roborts. }\end{array}$ & 3rd August & . & • & 30 th September, 1905 & do. \\
\hline
\end{tabular}


List of officers who have attended a course of instruction or studied at the Laboratory-contd.

\section{\begin{tabular}{c} 
Name. \\
\hline 1906-1907
\end{tabular}}

Captain W. B. Edwards.

Lieurenant W. C. Lowe.

Cipptivin J. Farmer . Lientenant F. C. Russel.

MI. J. S. Jethiji

1907-190s.

Licutcnant $R$. Matthews. Mr. S. H. Gaiger

1908-1909.

Mr. C. T. D'Silva . MIr. D. A. D. Aitchison IIr. S. H. Gaiger

1909-1910.

Captain W. O. Dawson.

Captain R. C. Coehranc.

Contain M. St. G. Glasse.

1911-1912.

Cajtain W. A. Wood

\begin{tabular}{|c|cc} 
Date of arrival. & Date of departurc. & $\begin{array}{c}\text { Period of } \\
\text { course. }\end{array}$ \\
\hline
\end{tabular}

:

29th July : : End of Sicptember,

. . End 1906.

:

31st July

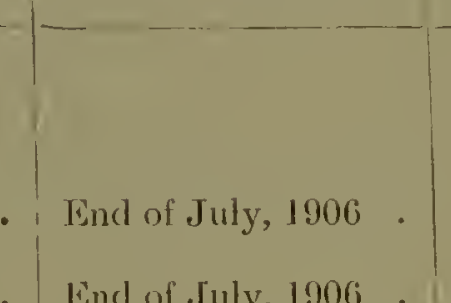

2 months.

1st Juno

1906.

End of September, 4 months. 1907.

End of Septomber, 3 months. 1907.

do.

do.

do.

do. 21st MIay

14th Junc, 1908

1 month.

1 week.

$2 \frac{3}{2}$ months.

4 th July 27th September, 1909

$2 \frac{3}{3}$ months.

18th September, 1909

24th February, 1910. 51 months.

18th June, 1910 .

12th August, 1910 .

$1 \frac{3}{4}$ months.

11 th May, 1911 26th August, 1911 .
3.2 months. 


\section{CHAPTER II.}

\section{Short Description of the Site and Buildings.}

Muktesar, locally known as Motesar, is situated at the summit of a hill on the inner Himalayas at an elevation varying from 7,500 to 7,702 feet. It is 23 miles by the bridle road North-East of Naini 'T'al and 13 miles south-east of Ahmora. The Railway terminus Kathyodam is reached by two direct routes; one passing through Dhari and Champi to Bhim Tal (16 miles) and from hence direct to Kathgodam (8 miles). The other road goes through Ramgarh (Dâk Bungalow) (10 miles) and hence to Bhim Tal (11 miles) here joining to Kathgodam.

The Laboratory estate comprises 7,000 acres, about half of which is covered with oak forest and chir. The Furka, a tributary of the Kosi runs through the estate. Numerous bridle paths have been made: connecting the Central Buildings with the out-Kraals situated at distances of 1 to 2 miles from the Laboratory.

The care of the forest and of the cultivation is in the charge of the Farm Manager assisted by the Farm Overseer, two Jemadars and some 300 to 400 coolies.

A nursery garden is kept up and about 6,000 plantings of Deodars, Chir, Walnuts, etc., are made each year.

\section{The Laboratory Main Building.}

The main building with its accessory buildings is sitnated at an elevation of 7,500 feet. The Laboratory is two storied and constructed of stone. The whole building is practically fireproof, the roof being of corrugated iron and the floors of stone slabs. The second story rests on iron supports on which are laid iron sheets, covered with cement on which stone slabs are laid.

Wide verandahs on both stories run along the south and west side. All ithe microscope rooms face north. There are three entrances from the sonth side to the east, west and new wings.

The east wing on the ground floor contains the Head Clerk's Office, general office for clerks, Chemical Store rooms and an office for the records connected with the preparation and testing of all serums and vaccines. 
On the second floor are the Imperial Bacteriologist's Offiee and Work Room (two benehes), the Photography rooms and the Chemieal Laboratory.

In the west wing the three Library rooms oecupy all the ground floor, while above are a mierotome room and two microseopie rooms for three worlicers.

The new wing on the ground floor contains an offiee for the European Laboratory Assistants, a large room for gencral work, a media room and an ineubator room. The sccond storey is comprised of the Assistant Baetcriologist's Office and work room (three benehes) and a large room for the work for the European Laboratory Assistants.

All the rooms are thoroughly equipped with all neessary apparatus and provided with water, gas and elcetric light. The walls are lined with glazed tiles and the floors laid with marble slabs.

The library contains some 3,500 volumes and subseribes to 101 scientifie journals.

Close to the main building are situated the Sterilising House and Media preparing room, the eentrifuge and serum house, the serum filling and bottling house, two cold storage rooms, the packers and earpenters house, small animals' housc, grain godown and store, and the Farm Manager's Office and Power House and Work Shop.

The eleetric plant has recently been installed and is used to drive the serum ecntrifuges, small ecntrifuges in the Laboratory, ehaff cutter and saw, and also to light the main and other buildings.

The serum centrifuges are of two litre eapacity manufactured by Messrs. Baird and Tatlock to as special design as follows :-

The armature shaft takes the bueket supports. The armature is in a cast iron casing bolted down to a masonry foundation and the spindlc instead of working between bushes and on a stud works on a plate with ball bearings above and below. These eentrifuges give a high perecntage of clcar serum. The time required for spimning is less than half an hour.

\section{Sheds (West).}

On the west side of the Laboratory are situated the sheds for the accommodation of the animals used in preparing Anthrax serum, Hæmorrhagic Septicæmia sermm and a Black Quarter vaceine, two operating sheds, a stable for Surra experiments, a stable and post-morten house for Glanders experiments and out-Laboratories for Anthrax Black Quarter and Mallein. 


\section{Out-Laboratories.}

Each of these out-Laboratories consists of two large rooms ; one contains incubators and sterilisers, the other is equipped as a microscopic room.

All the work eomnected with serum preparation and investigation in Anthrax, Black Quarter and Mallein, is carried out in their respective out-Laboratories. This prevents the risk of the infection by sporulating organisms and of Glanders being brought into the main Laboratory, and tends to the general safety.

\section{Sheds (East).}

On the east side are situated the sheds for the accommodation of eattle used in the preparation of Rinderpest serum, three operating sheds, a post-mortem house, ineinerator, two stables and dog kennels. All the eattle sheds are stone buildings with eorrugated iron roofs, lined with wood. The floors are laid witl stone slabs, with open drains. Each shed aceommodates from 15 to 30 animals. The operating sheds are eomposed of three rooms, viz., a large operating room with glazed tiles lining the wall, floor of slabs, and doors with windows provided with fly proof attachments, an inner room for storing apparatus, etc., and an outer room for temporary accommodation of animals.

\section{Post-Mortem Room.}

The Post-Mortem House has two rooms. The outer room in which the carcases are prepared for examination is provided with operating tables, sinks, etc. The inner room is equipped as a microscopic room, and contains facilities for the immediate examination of tissue, preparation of cultures, etc. The walls of both rooms are lined with glazed tiles and the floors and benches are covered with marble slabs.

\section{Out-Kraals.}

The Out-Kraals, which are six in number, are situated from 1 to 2 niles from the Laboratory. They provide accommodation for a reserve supply of animals and for mimals which have been under experiments and which are being lept under observation for a long period. These Kraals are also required for the segregation of eattle accidentally infected with foot and mouth disease or any other accidental infection. 
The Kraals are surrounded by a wall 13 feet high to protect the cattle from attacks of wild animals during the night. The sheds open into a large open yard. The floors of the sheds and of the yard are of stone slabs. Each yard is provided with a watering trough fed by pipes from springs.

The Dispensary and Hospilal.

The building is situated near the Post Office and Bazarr (Native Shops).

It has the following accommodation :-

One ward with eight beds for menial establishment.

One ward with two beds for the subordinate staft.

Attached to each of these wards is a kitchen, bath room, store room, yard and latrine.

An operating room.

A dispensing room and store room.

A segregation ward for infectious diseases is situated at a distance of about 200 yards from the Hospital. It contains four beds and an attendant's room.

The quarters of the Sub-Assistant Surgeon are attached to the Hospital. The compounder's quarters are separate at a short distance from the main building.

The average number of patients treated daily at the Dispensary is twenty-five.

\section{Visitors' Bungalow.}

The Visitor's Bungalow was built for the accomn odation of officers on training and officers visiting the Laboratory. There are four bedrooms with dressing and bath rooms attached, and a large dining room, all fully furnished. A Khansama is kept at the Bungalow and meals are supplied at the usual rates.

The Inspection Bungalow, Public Works Department.

This bungalow was formerly comnected with a Government Orchard which is part of the Laboratory estate. It now belongs to the Public Works Department and is used as a residence for the Officers of that Department when visiting Muktesar on duty. 


\section{The Instilule.}

The Institute was built in 1906 for the recreation of the staff. It has a large reading room, a library room and a card room. Three tennis eourts and a badminton eourt have been eonstructed. The institute is run on the lines of a Club open to all members of the staff who pay a monthly subseription in proportion to their pay. It is well provided with books and periodieals.

\section{The Branch Laboralory, Bareilly.}

The Laboratory is situated about four miles outside Bareilly Cantonment on the Budaun road. It was built in 1901 for the purpose of carrying on eertain investigations during the winter months of each year. The main building contains two offices, two mieroseope rooms and a sterilising room. There are five eattle sheds to aeeommodate about 100 animals, two operating sheds, a post-mortem house and ineinerator and a store godowll, and quarters for a European Laboratory Assistant and for four other clerlss. The Laboratory stands in 30 aeres of ground. 


\section{CHAPTER III.}

\section{Research Work and Publications.}

By Dr. Lingard, Imperial Bacteriologist, 1890

-1907 .

Surra.

Investigation on Horse Surra.

Investigation on Camel Surra.

Investigation on Surra Treatment.

The investigation on Surra was continued throughout Dr. Lingard's service. The result of his experiments are eontained in :-

(i) Report on Surra, 2 Volumes (Govermment Publieations) and Annual Reports for 1895-96, 1896-97 and 1897-98.

(ii) Summary of further Reports on Surra during 1894 (Government Publieation).

(iii) Summary of further Reports on Surra during $189 \jmath$ (Government Publieation).

(iv) Report on an outbreak of Surra and Filariasis at Karnal Depôt during 1896. (Machine Press, Mecrut).

(v) Through what ageney is Trypanosoma Evansi carried over from one Surra season to another. (Journal of Tropieal Veterinary Seience, Vol. I, No. 1, 1906.)

\section{Rinderpest.}

The investigation of Rinderpest; the inethods of preparing a potent antiserum ; the bile method of protection ; the suseeptibility of various breeds of eattle in India and the doses required to proteet cattle of different breeds, etc., were commeneed in 1898 and continued for several years.

(i) The results are given in a speeial report on Rinderpest and Serum preparation (Government Publieation) and in the Annual Reports for 1898-99, 1899-1900, 1902-03, 1903-04, 1904-05, 1905-06 and 1906-07.

(ii) Note on the different degrees of suseeptibility to Rinderpest cxhibited by the various pure and mixed breeds of bovines and buffaloes, ete., subnitted to serum testing by the "Serum alone" and "Simultaneous Methods" during the year 1899-1903 (Government Publieation). 


\section{Epizootic Iymphangitis.}

This disease was first diagnosed and described in India by Dr.

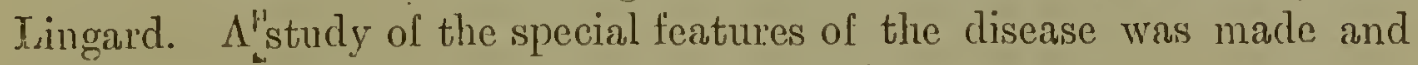
diagnosis of suspected cases carried out for six years.

Annual Reports 1899-00, 1900-01, and 1901-02.

\section{Dourine.}

$\Lambda$ study of the characteristics and etiology of this disease of horses was made by Dr. Lingard and published in a special report.

(i) Dourine Report (Government Publication). Annual Report 1902-03.

(ii) The Trypanosoma of Dourine and its life History. (Centralblatt für Bacteriologie. Parasitenkunde und Infektionskrankheiten. Bd. XXXVII, Heft 4 (1904).)

(iii) Further notes bearing on the T. Equiperdum. (Journal of Tropical Veterinary Science, Vol. I, No. 4.)

\section{Seruins.}

Antiserums were prepared against Rinderpest, Hæmorrhagic Septicæmin, Anthrax and a double vaccine for Black Quarter.

Anmual Reports, 1900-01, 1901-02, 1904-05 and 1906-07.

\section{Other Publications.}

(1) Observations on the Filarial embryos found in the general circulation of the Equidx and Bovidæ and their probable pathological significance (Adlard \& Son, London).

(2) A Preliminary note on a Pyroplasma found in man and some of the lower animals. (Indian Medical Gazette, Vol. XXXIX (No. 5, May, 1904).)

(3) $\Lambda$ contribution to the knowledge of protection against Infectious Diseases. (The Proceedings of the Royal Society, Vol. 45.)

(4) Resistance against Rinderpest and other infectious diseases by bile products and also from substances prepared from animal testes and seeds of plants.

(Centralblatt für Bakteriologie, Parasitenkunde und Infektionskrankheiten, Bd. XXXVII, Heft 2.)

(5) A short account of the various Trypanosomata found in India in the blood of some of the lower animals and fish. (Indian Medical Gazotte, Vol. XXXIX, No. 12.) 
(6) Ocular Filarix of Equines and Bovines. (Journal of Tropical Veterinary Science, Vol. I, No. 2.)

(7) A new species of Trypanosoma fonnd in the blood of rats together with a new metrical method of standardising the measurements of Trypanosoma. (Journal of Tropical Veterinary Science, Vol. I, No. 1.)

(8) Flagellates found in the Gastro-intestinal tracts of the Horse leech. (Journal of Tropical Veterinary Science, Vol. I, No. 3.)

(9) Different species of Trypanosomes observed in bovines in Tndia. (Journal of Tropical Veterinary Science, Vol. II, No. 1.)

(10) Some forms of spirochatosis met with in animals in India. (.Tomrnal of Tropical Veterinary Science, Vol. II, No. 3.)

By Captain Leonard Rogers, Officiating Im. perial Bacteriologist, $1898-1900$.

By Major J. D. E. Holmes, Imperial Bacteriolo. gist.
Report on an Experimental Investigation of the methods of inocnlation against Rinderpest. (Govermment Publication, 1900.)

\section{Surra.}

Fxperiments on the treatment of Surra in Horses, Camels, and Dogs. The cure of surra in horses.

The cure of surra in dogs.

Description of trypanosoma found in cattle in India. Investigation of the evolution of the Surra Trypanosome.

Details of these experiments are given in the following publications :-

(a) Investigation of an ontbreak of horse surra with the result of treatment with Atoxyl, Tartar Emetic, Mercury and other drugs. (Civil Veterinary Department, Memoir No. 1.)

(b) Treatment of surra with Atoxyl and Orpiment and other preparations of arsenic. (Civil Veterinary Department, Memoir No. 1.)

'c) The treatment of surra in horses by means of Arsenic and its derivatives. Thirty-two cases of successful treatment. (Civil Veterinary Memoir No. III ; Journal of Parasitology, Vol. III, No. 1 of 1910 and Journal of Tropical Veterinary Science, Vol, V, No. 1.)

(d) The cure of surra in horses by the administration of Arsenic. (Journal of Parasitology, Vol. III, No. 3, Octoher 1910. Civil Veterinary Department Memoir No. III and Journal of 'Tropical Veterinary Science, Vol. VI, No. 4.) 
(e) A further note on the cure of surra in horses. (Civil Veterinary Department Memoir No. IIT.)

(f) The treatment of surra in lorses and dogs by means of Salvarsan. (In Press.)

(g) A trypanosome found in the blood of cattle in India. (Journal of Comparative Pathology and Therapentics, Vol. XVII, 1904.)

(h) Evolution of the Trypanosome Evansi. (Journal of Comparative Pathology and Therapentics, Vol. XVII, 1904.)

(i) The role played by biting flies in the spread of Trypanosomiasis. (Journal of Tropical Veterinary Science, Vol. I, No. 2, 1906.)

(j) The cure of surra in horses by a combination of Tartar Emetic, Atoxyl and Arsenic. (In Press.)

(k) Surra; Cures of Spontaneous cases. (In Press.)

\section{Rinderpest.}

Testing of susceptibility of cattle from various districts in India.

Experiments regarding improved methods of Rinderpest serum preparation.

Preparation of serum by injections of Peritoneal fluid.

Preparation of serum by the exclusive use of plains cattle and buffaloes.

Investigation regarding the nature of immunity conferred by the serum alone method and serum simultaneous method in Rinderpest.

\section{Publications.}

(a) Some diseases complicating Rinderpest among cattle in India. (Journal of Comparative Pathology and Therapeutics, Vol. XVII, 1904.)

(b) The "serm alone" method as a means of combating Rinderpest in India. (Civil Veterinary Department Memoir No. 1.)

(c) Rinderpest. Report to Govermment of India (Civil Veterinary Department Memoir No. III).

\section{Anthrax.}

Investigation into method of preparing a potent antiserum ; the susceptibility of stock in India to inoculated Anthrix and on the practical value of Anthrax antiserum and vaccines in combating the disease in $I^{\text {ndia. }}$ 


\section{Publications.}

(a) The practical value of Anthrax antiserum and vaccines (Preliminary Report). (Civil Veterinary Memoir No. III.)

(b) The method of sero-vaccination against Anthrax. (In Press.)

\section{Hamorrhagic Septicrmia.}

Investigations into methods of preparing a potent antiserum and a dead vaccine. Testing the application of the serum and vaccines in protecting susceptible animals. Testing the susceptibility of animals of different species to the inoculated virus. Experiments regarding the etiology of the disease and vitality of the organism, etc.

\section{Publications.}

(a) Immunisation against Hæmorrhagic Septicæmia of Bovines. (Civil Veterinary Department Memoir No. 1.)

(b) Further testings of the Hæmorrhagic Septicæmia antiserum and vaccine. (Civil Veterinary Department Memoir No. III.)

(c) The vitality of the Inemorrhagic Septicnmia organism ontside the body. (In Press.)

\section{Charbon Symptomatique.}

The preparation and testing of a suitable single vaccine to protect against Black Quarter.

The preparation of an antiserum.

\section{Publications.}

(a) Immunisation against Charbon Symptomatique by means of a single vaccine. Description of a special vaccine pillule injector. (Jonrnal of Tropical Veterinary Science, Vol. 4, 1909, and Civil Veterinary Department Memoir No. 1.)

\section{Lymphangitis of Cattle.}

Investigation of a new discase which appeared among the cattle of the Transport Depôt in Calcutta in 1908. 


\section{Pubtications.}

(a) A peculiar form of streptotrichosis among cattle. (Civil Veterinary Department Memoir No. $i$ and Journal of Tropical Veterinary Science, Vol. III, 1908.)

\section{Ralin.} rats.

Testing the practical value of this preparation in the destruction of

$$
\text { Piroplasmosis. }
$$

Description of a Flagellate form of Piroplasm Bovis. (Civil Veterinary Department Memoir No. 1.j

\section{Bursaiti.}

The etiology and treatment of Bursati. (In Press.)

\section{Other works.}

An investigation as to the cause of mortality among serum preparing animals.

Investigation of Abrus poisoning in cattle.

\section{Publications.}

(a) Anaphylaxis in the larger animals. (In Press.)

(b) Cattle poisoning by seeds of Abrus Precatorius in India. (The Veterinary Journal, Vol. XI, 1904.)

Other publications from the Laboratory by Major J. D. E. Holmes.

(1) An outbreak of Diphtheria associated with a similar disease among fowls and a visicular ermption on the udder of cows. (Journal of Comparative Pathology and 'Therapeutics, Vol. 17, 1904, pages $1-47$.

(2) A note on elements resembling spirochætes fonnd in blood preparations from man and animals. (Civil Veterinary Department Memoir, No. III.)

(3) A note on some interesting results following the internal administration of Arsenic in Canker and other diseases of the Fret in horses. (In Press.) 
By Minjor Baldiey. Oftriating Iinperial Bucteriologist, from February to becember, 1910.

By Lientenant $\mathrm{G}$. $\mathrm{K}$. Walker, Assistant Broteriulogist, 1898-1901.

By Mr. R. E. Montgomery, $\Lambda \mathrm{s}$ sistant Baoteriulogist, $1904-1906$.

By Mr. H. E. Cross, Assistant Baeteriologist.

By Dr. P. Hartloy, Physiological Chomist.
(1) Preparation of Anti-Rinderpest Serum by means other than the injection of virulent blood. (Joumal of 'Tropical Veterinary Scienee, Vol. VT, No. 1 of 1911.)

(2) Feeding and immunity in Homorrhagie Septiexmia and Rinderpest. (Journal of Tropieal Veterinary Scienee, Vol. VI, No. 2 of 1911.)

(3) A cultural method of hyper-immunising animals for the prodnetion of Anti-Rinderpest serum. (Journal of Tropieal Veterinary Seience, Vol. VI, No. 3 of 1911.)

(4) Sensitised vaccine in Hæmorrhagic Srptiexmia. (Journal of 'Tropical Veterinary Scienee, Vol. VI, No. 3 of 1911.)

(5) The evolution of Trypanosoma Evansi through the fly Tahanus and Stomoxys. (Journal of Tropical Veterinary Scienec, Vol. VI, No. 3 of 1911.)

(6) An undescribed organism Pathogenie to Laboratory animals, cattle and sheep and simmlating Black Quarter. (Jommal of 'Tropical Veterinary Science, Vol. VI, No. 3 of 3911.$)$

(7) Observation on Normal and Rinderpest blood. (Journal of Tropical Veterinary Seience, Vol. T, Part I.)

Rabies in dogs, wolves, jackials and foxes. (The Agriculture Ledger, Special Veterinary Series, No. 10, 1899.) (Government Publication.) The Cattle of Kumaon. ('The Ayriculture Ledger, Veterinary Series, No. $28,1899$.

(1) Ohservations on Bilharziosis among animals in India. (Journal of Tropical Veterinary Scicnee, Vol. I, part I, also Vol. I, part II.)

(2) An Anthrax-like Bacilli found in a horse suspected of Anthrax. (Journal of Tropieal Veterinary Scienee, Vol. I, part III.)

The preparation of Anti-Rinderpest Serum by injection of virulent artifieial peritoneal washings. (Civil Veterinary Departnent Memoir No. III.).

(1) On the immune bodies oeeurring in Rinderpest immune serum. (Civil Veterinary Department Memoir No. III.)

(2) Report on the preparation of Rinderpest Anti-serum by means of diluted virnlent fluids. (Civil Veterinary Department Memoir No. III.)

(3) On the immune bodies oecurring in Rinderpest Immune Serum. Part II. (In Press.)

(4) On some ehanges oceurring in the eomposition of the serum of animals during Rinderpest. (In Press.)

(5) On some ehanges oceurring in the composition of the serum of animals during immunisation against Rinderpest. (In Press.) 
Biliary Fever: of horses in India.

(The Veterinary Jourual, Vol. XI, 1994, pages 30-40.,

$\Lambda$ trypanosoma found in the blond of cattle in Iridia. (Journal of Comparative Pathology and Therapeuties, Vol. 17, 1904.)
By Liente- mant S. T. C. P'illin, Arny Veterinury Corps.

By Captain H. M. Jur. lant, Army Veterinury Corps, with ('ilptain J. D. E. Hones.

Some treatments of Surra (Trypanosomiasis Equi) as carried out at By Capt.in the Imperial Bacteriological l.aboratory, Muktesar. (Indian Veterinary Wy. U. DawJournal, English Edition, Vol. I, 1910.) (i)II 


\section{CHAPTER IV.}

\section{The Practical Application of Serums and Vaccines in combating infective Diseases of Stock in India.}

The problem of dealing with infective diseases of animals in India presents many difficulties peculiar io iocal conditions. In a country like India where measures of treatment, segregation or of police restriction camnot be imposeci in the suppression of epidemies of stock, owing to the prejudices and feelings of the majority of native farmers, and also where the areas to be dealt with are so vast and frequently so difficult, no direct attempt at the total eradication of any endemic infective disease is feasible. Even if it were possible to cradicate a disease from any one province or from the whole of British Territory in India it would be impossible to prevent its re-introduction throngh the frontier line. Consequently, the operations of the Govermment Veterinary Department are directed towards the suppression of outbreaks of epizootics as they occur, the treatment and protection of individuals being of less consideration and any systematic attempt at total cradication not being attempted.

Even this task of controlling the spread of infection is one of very considerable difficulty, as full and effective measures camot be put into operation. The Veterinary Service has to rely solely on the aid of serums and vaccines and these can be used only when the owners consent to have their cattle treated. Neasures of segregation and disinfection cannot be imposed without the sanction of each individual owner. The scarcity of fuel adds to the difficulty of disposal of infected carcases.

Glanders, Surra, Lymphangitis Epizootica and Dourine are the only aiseases for the control of which legislative measures are in force. At the present time, after practical demonstrations of the benefits of serum injection in outbreaks of Rinderpest, during the past ten years, the use of serum is accepted without opposition in most districts of India. On the part of the Veterinary Service every care has to be exercised that whatever measures are adopted in dealing with an outbreak they shall be free from any danger to the lives of the animals treated, and shall in no way interfere with their work. Serum-therapy has proved to be the safest and most efficient method of operation under such couditions. 
Dead vaccines can also be used with safety and confer an immunity of somewhat longer duration than the serum alone process, but they are less suitable in face of actual ontbreak, as the protection indnced by them is not established for some days after the injection.

Vaccination by mems of living but altenuated organisms is not practised, except against Black Quarter, as a prophylaxis in districts where the disease is seasonally prevalent. The danger of accidents following inoculations, of losses among treated cattie, and of establishing fresh foci of infection precludes this method from general practical use.

For the sarne reason the method of Sero-vaccination which consists of a combined injection of a virus and its anti-serum is not of general practical application in this country.

\section{Rinderpest.}

In India Rinderpest is the most prevalent and destructive disease of stock. The use of sermu has proved of very great value in protecting cattle and in controlling the spread of infection. The immunity following c.n injection of serum lasts for two or three weeks only, but it has been found both by experiments and in practice that animals which receive an injection of serum and are exposed to actual infection within the period of protection, may contract a mild form of the disease which gives an active immunity of long duration.

Serum not only preserves the lives of the amimals treated but it checks the spread of the disease, as the immunised animals are no longer a medium for the existence and transmission of the infection.

Indirectly the use of serum combined with actual exposure to infection by producing ail active immunity and thereby increasing the number of immune cattle, is a factor which operates towards the ultimate eradication of the disease. In infective disease of a more sporadic nature, serum operations are less effective and more difficult to apply.

\section{Anthrax.}

An outbreak of Anthrax spreading anong and causing a number of losses among animals in one locality is not of frequent occurrence. In some districts the disease is prevalent during and immediately after the rains. Its appearance in any one locality is intermittent and seldom causes more than a few deaths at each visitation. 
Sermm aflords a temporary protection to individual animals. By two or more injections it is possible to tide the animals over the time during which the disease is prevalent. Where Anthrax appears in an epidemie form among one or more herds or in a stable, the application of serum injections, not only affords an immediate proteetion to all the animals exposed to infection, but it stops short the spread of the disease and gives facilities for carrying out thorough measures of disinlection.

Vaccination against Inthrax camnot be recommended for practice in India. The action of the vaceine is irregular and not infrecpuently a considerable pereentioge of deaths result after vaceination, which form fresh foci of infection.

Sero-vacination, which is a combined injection of serum and virus at the same time lut on different parts of the body, is attended with less risk than the vaccine and confers a durable immunity. Among a valuable herd of cattle or in a stable where the owner is willing to aecept the risk of a few losses, the seru-vaccination method is the most satisfactory method of protecting against Anthrax.

\section{Hamorhatgic Septicamia.}

After Rinderpest, Hannorrhagic Septicienia accounts for the largest losses anong cattle in India. This disease is prevalent throughout the country. Onthrealis generally occur sporadically during and after the rains and seldom assume an epidemic form. In dealing with this disease, serum is used, as in Antlurax, to protect animals exposed to infection during the period the disease is prevalent, or until, where possible, measures of disinfection can be carried out and the source of infection removed.

A dead vaecine has been prepared whieh gives an immunity of about six weelis. This vaeeine is of considerable advantage in localities where the disease is seasonally prevalent. Cattle are inoeulated and put in a state of protection before the disease has actually appeared among them.

Sero-vaceination is also a safe and effieient method of immunising animals against this disease, but ought not to be practised in areas free from infection and only when owners do not object if a small percentage of loss follows inoculation.

\section{Black Quarler.}

Charbon Symptomatique or Blaek Quarter is a disease which is more or less connined to certain areas and apjears seasonally during the 
rains and seldom assumes epidentic form. A serum for this disease has been prepared but it is not of mueh pritutical value as the protection afforded is only of about ten days cluration.

Vaccination has proved to be the most satisfactory method of combating this disease. 'The vaceine is composed of the living but attenuated organism and confers an active immunity which persists for several months. Vaceination is earried out each year among animals in infected districts immediately before the season when the discase makes its appearance. 'The vaccine is so attenuateö that few ancidents are traccable to its use.

\section{Strungles.}

As India is not to any great extent in horse breeding country, strangles requires very little intervention except in the Govermment Remount Depôt. A deard vaceine and a serun has been prepared and has beeu used with advantage unong Remounts.

\section{Glanders.}

Glinders is very prevalent throughout Ludia and Mallein is in all suspected cases used for diagnostic purposes.

\section{Truberculosis.}

Tuberculosis is not a conmon disease of stock in India. 'T'uberculin is consequently not much in demand.

\section{Telunus.}

Tetanus is widespread in the soil but cases of Tetanus in horses are not very numerous and the 'Tetanus antitoxin is only occasionally required.

\section{Surra.}

A suecessful method of curing Surra in horses by means ef Arsenic and Atoxyl has been worked out and instruetions regarding the doses and methods of administration of Arsenic and Atoxyl are issued from the Laboratory.

In using serum and vaccines in Veterinary practice disappointment is sometimes caused by an exaggrerated idea of the possibilities of these agents and an ignorance of their legitimate applieation. 
The following points should be borne in mind:-

(1) No serum can eonfer anything more than a temporary proteetion aggainst its speeifie disease. The periods for whieh serums proteet vary in different diseases from two weeks to not more than six weeks.

(2) In using serum the objeet aimed at is not so mueh the preservation of eaeh animal treated, as the eontrol of the epidemie and the prevention of the spread of the infection.

(3) No serum or vaceine will protect every animal treated. Many individuals eannot be inmmunised either on aeeount of an intense suseeptibility or more frequently from the existence of an intereurrent disease.

(4) The duration of the immmnity afforded by a serum or vaceine is not in every instance exaetly the same. Some animals are proteeted for a shorter time, others for a period longer than the average.

(5) Sermm gives an immediate protection. With vaceines the inmunity is not established for a few days after the injection. Dead vaecines give a protection for a somewhat longer period than serums. Living vaeeines produce an aetive immnnity of long duration (several months to one or two years) but their use is attended with the risk of a simall percentage of deatlis due to vaecination. 


\section{CHAPTER V.}

Serums and Vaccines prepared at Muktesar.

In the preparation of sermm, a quantity of blood is drawn of from the hyper-immmised amimal into sterile glass flasks containing eoils of eopper wire. The blood is immediately defibrinated, after which it is placed in eleetrieally driven eentrifuges revolving at a speed of about 4,000 revolutions per minute. The clear fluid is drawn off, and bottled in five and ten litre flasks and stored in the cold room. Carbolic aeid is added to the serum to the extent of 0.5 per eent. When suitable quantities of serum have been eolleeted, it is mixed in a 300 litres enamel cask, and tested for potency and sterility. When tests are eompleted the serum is numbered and bottled for issue in brown glass stoppered bottles of 100,250 and 500 c.e. eapacity. The stoppers are sealed and covered with waxed eloth to prevent possibility of eontamination entering the serum.

A reeord of the tests of eaeh brew of sermm issued is filed for reference.

A statement of the poteney of each serum and rules for its administration are forwarded with eaeh issue of serum.

\section{Anti-Rinderpest Serum.}

This serum was first prepared by Kolle and Turner in South Africa and used there with sueeess in 1898 .

The following year it was manufactured at Muktesar and its use introduced into India.

The serum is prepared from eattle whieh have been first immunised against Rinderpest and further treated with one or more injeetions of virus. The virus is obtained from animals suffering from the disease. Lingard by a large series of experiments extending over three years worked out an eeonomical method of preparing a serum of high poteney. In the early operations with serum much opposition was experienced from the owners of eattle who regarded the interferenee with suspicion and refused to allow their animals to be treated.

$\Lambda$ fter a few years, the suecessful results overeame this opposition, and the demand for this serum inereased at sueh a paee that from 1907 to 
1910, the maximum output (of about 500,000 doses) was insufficient to meet the orders for serum.

In 1910 improved methods of preparing this serum were diseovered, by the applieation of which in the following year over 1,000,000 doses were manufactured, at the same eost as was previously necessary for half this amount.

This serum was, up to 1910, issued free of cost to the Civil Veterinary Department in each Province, but in this year a charge of two amas per dose was imposed, and surplus sermm not required by the Veterinary Departnent was made available for purchase by Native States and other Govermments, ete.

Each brew of serum which consists of from 50,000 to 100,000 doses is carefully tested and the protective dose for susceptible cattle ascertained per $600 \mathrm{lbs}$. body weight.

All brews which show potency sufficient to protect, at a dose of 90 e. e., a susceptible animal of $600 \mathrm{lbs}$. body weight, are issued.

Brews of lesser potency are rejected or raised by admixture of stronger serum to the required strength.

Each brew of serum is accompanied with the following set of rules as a guide to the method of operation and to the fixing of suitable doses:-

\section{Serum No.}

INSTRUCTIONS For INOCULATING BOVINES WITH AN'I-RINDERPEST Serum.

Manufaetured at the Imperial Bacteriological Laboratory, Muktesar.

$$
\text { By" Serum Alone" Method. }
$$

\section{Serum Alone.}

N.B.-No virulent blood to be used.

(1) The "Serum Alone" method is to be used only in actual outbreaks of Rinderpest. It serves to protect animals from contracting the discase and thereby curtails the spread of the infection. The immunity conferred by a single dose of serum is of short duration, varying from three to six weeks. Consequently, if eattle are subjected to infection for a longer period they should be reinoculated.

(2) The serum is injected subeutaneously in the region of the shoulder and, for this purpose, the hair should be elipped over a small area of 
about 2 inches diameter, and the part washed with a 5 per cent. carbolic solution before introdncing the needle of the syringe. After injecting the fluid withdraw the needle placing one finger or thumb over the small tumonr made by the injected sermu in order to difluse the fluid downwards into the surrounding tissues before letting the animal loose.

After inoculation with serum alone, all the animals should be tmined out together with the infected herel in order that an opportunity of contracting natural infection and a longer imnunity nua be given.

Bullocks nay be worked on the day following the serum injection.

(3) Steudardised dose of serum:-

For Hill cattle per 600 lbs. body weight, 90 c. c.

(4) Eacl brew of serum is tested before issue on cattle of Hill breed which are nost susceptible to Rinderpest.

T'le protective dose is the amount of sermu necessary to protect a Hill bull weighing 600 lbs. against a simultaneous inoculation of a lethal dose of virnlent blood.

No brew of sermu is issued which does not protect at a dose of 90 c. c. per 600 lbs. body weight of Hill cattle.

(5) For Plains cattle the dose of serum cannot be standardised owing to the varying susceptibility of cattle throughout India.

1 dose of 5 c. c. per 600 lbs. body weight has been found sufficient to protect village cattle of the lowest susceptibility.

Doses from 10 c. c. upwards are required according to the susceptibility of the cattle as evinced by the severity of the outbreak.

It remains the duty of the Veterinary Officers in charge of the operations to regulate the dose of serum for the cattle of their district.

(6) The following instructions have been formulated with a view of assisting in regulating the dose of serum for Plains cattle :-

(i) Doses of 10 to 30 c. c. per 600 lbs. body weight should be used under the following circumstances :-

(a) When from observations of the mortality among nontreated animals there is evidence of a high scale of susceptibility.

(b) When the outbreak is widespread and it is probable that animals will be exposed to infection for a considerable period. 'The increased dose gives protection for' a longer' period. 
(c) For cattle such as Conservancy bullocks, Transport and Dairy cattle, which are kept under favourable conditions and not so exposed as are village cattle to natural infection. Such animals probably possess less immunity.

(ii) All imported cattle . ) Require a dose of not less than Country bred cattle with im- $\{90$ c. c. per 600 lbs. body ported strain .
Hill cattle .

(7) The following doses are recommended for the treatment of bovines in the Military Service:-

$$
\text { By "Serum Alone" Method. }
$$

Dose of serum recommended for:-

(I) (a) Imported cattle - For animals weighing $600 \mathrm{lbs}$. and under, $100 \mathrm{c.c}$.

(b) Country bred cattle For animals over $600 \mathrm{lbs}$. the with imported strain . $\}$

(c) Hill cattle. $\cdot \cdot \int \begin{aligned} & 20 \mathrm{c} . \mathrm{c} . \\ & 100 \mathrm{lbs} .\end{aligned}$

(II) Plains cattle weighing $600 \mathrm{lbs}$ and under . . 30 c. c. (For animals over $600 \mathrm{lbs}$. the dose should be increased by 10 c. c. for each additional 100 lbs.).

(III) Calves (1 to 12 months)-

Imported calves. . . . . 50 c. c.

Country bred with imported strain $\quad .50$ c. c.

Country bred . . . . 20 c. c.

For calves over 12 months full dose as for No. I and No. II may be used.

(8) List of necessary instruments, etc., indispensable for inoculations in the field.

(1) 20 c. c. syringe for injecting serum.

(2) 1 small glass bottle for pouring serum into from large bottie in order to fill syringes.

(3) 1 small open vessel for carbolic acid solution.

(4) 2 clinical thermometers.

(5) 1 bottle containing 5 per cent. carbolic acid solution. 
(6) cotton wool.

(7) 1 corkscrew for opening serum bottles.

(8) 1 pair of scissors.

(9) 2 ropes for casting animals.

(10) 1 measuring tape.

The serum alone method of operation as practised by the Civil Veterinary Department is as follows :-

On receipt of information of an outbreak of Rinderpest the Superintendent, Civil Veterinary Department of the I'rovince, arranges for a supply of serum to be despatched to the seat of the outbreak and also sends as many trained Veterinary Assistants as are available to carry out serum injections.

All eattle for which the owners give consent, in the infected villages and in villages in close proximity, are injected with serum alone in order to cut short the spread of the disease.

The serum-injected cattle are mixed with the infected animals so that they may have an opportunity of contracting a mild form of the disease and obtaining an active immunity.

That cattle injected with serum and subsequently exposed to infection do contract Rinderpest in a mild form and become actively immunised has been proved both by Laboratory experiments and by observations in the field. All serum-injected cattle, not directly exposed to infection, are, when possible, again injected with serum every two to three weeks until the epidemic has subsided.

Simultancous injections of serum and virus are practised by the Army Veterinary Service in the protection of Army Dairy Cattle.

For this purpose two Army Veterinary Officers underwent a course of instructions at the Laboratory during 1909-1910.

The serum is not much used as a curative. If the disease is not too far advanced in the stage of diarrhœa and collapse, intravenous injections of 100 c. c. and upwards of serum undoubtedly aid recovery.

\section{Anli-Anthrax Serum.}

Sclavo in 1895 was the first to prepare an Anthrax serum. He made use of sheep for this purpose and obtained a serum which when tested on rabbits showed both prophylactic and curative properties.

Sobernheim, at a later date, prepared Anthrax serum from the horse, cattle and sheep, and anvocated the continued use of a serum and an 
attenuated vaccine injected at the same time in different parts of the body. cattle.

Lingard, in 1902, produced an Anthrax serum by hyper-immunising

Recently an investigation has been completed on the susceptibility of cattle, shecp and equnines to inoculated Anthrax in India, the application of the sermm alone, vaccination and sero-vaccination methods of protecting against Anthrax to conditions existing in this comitry and the methods of preparing a sermm of high poteney.

Cattle in Tndia are little susceptible to inoculated Anthrix but a large number of deaths among cattle from Anthrax are reported anmmally, which are probally due to the ingested form of the disease. Sheep are most susceptible of both forms and equines are to a somewlat lesser degree than sheep susceptible to both inoculation and ingestion of the infection.

The incidence of Anthrax is sporadic and seasonal and rarely appears in epidemic form.

Serum injections are carried nut in the herds and stables where one or more deatlis from Anthrax have occurred and where, consequently, the animals are exposed to infection.

The object aimed at is to give these animals an immediate protection so that they can cither be removed from the infected orea or measures of disinfection be carried out.

The serum is used in doses of 10 to $50 \mathrm{c.c}$. The immunity prorheer is of about four weeks duration.

The scrum injected intravenously in doses of $100 \mathrm{c}$. c. and over has a curative effect in the early stages of the disease. For reasons already explained the methods of vaceination and sero-vaccination camnot be adopted for general practice in India.

The dose for cattle varies from 10 to $25 \mathrm{c}$ c., for sheep, 25 to $30 \mathrm{c}$ e.; and for horses 25 to $50 \mathrm{c}$. c. according to size. Anstralian horses being very susceptible require an injection of not less than $100 \mathrm{c}$. c. sermu.

The scrum is tested on sheep. A serum of very ligh potency protects slieep in a dose of $\tilde{J}$ c. c. Sermm which protects sheep in doses of 15 to $25 \mathrm{c}$. c. is of average potency and suitable for issuc.

The Anthrax serum at the Laboratory is prepared from cattle by repeated injection of Anthrax culture 48 hours old. Amounts up to 4 litres being injected at a time. Better results are obtained when the sediment of broth cultures or the surface growth from agar plates are added to the two days old broth cultures before injection. 
The following instructions are forwarded with all Antinrax serum sent out from the Lahoratory :-

\section{Sertin No.}

Instructions for Treating Bovines and Enuines with anterisax SERUM.

Prepared at the Imperial Bacteriologieal Laboratory, Mulitesar.

$$
\text { By "Serum Alone" Method. }
$$

I. The "Serum Alone" method is to be used in actual outbreaks of Anthrax. It serves to protect animals exposed to infection and thereby curtails the spread of the disease, and permits of measures being taken to rlisinfeet and remove the source of infection. The immunity conferred by a single dose of sermu, is of short duration, not more than fonr weeks. Consequently, if animals are subjected to infection for a longer period they should be re-injected.

II. 'The serum is injected subeutaneously in the region of the shoulder, and, for this purpose, the hair shonld be elipped over a small area of about 2 inclies diameter and the part washed with a 5 per cent. carbolic acid solution before introducing the needle of the syringe. After injeeting the fluid withdraw the needle placing one finger or thumb over the small tunour made by the injected serum, and diffuse the fluid downwards into the surrounding tissues.

III. The doses of serum are :-

For cattle according to size - . 10 c. e. to 25 e. с.

For sheep . . . . . . 25 e. c. to 30 c.c.

For ponies, mules and eountry-bred horses 25 e. e. to 50 e.c.

For imported horses . . . . $100 \mathrm{c}$. e. and upwards.

IV. Every preeaution should be taken to thoroughly disinfeet all instruments and hands, etc.

A bottle of serum that has been opener should not be used after 24 hours. The remaining contents should be disearded.

V. The serum is eurative and may be injected intravenously in quantities of not less than $10 u$ c. e. in animals suffering from the disease.

VI. Lists of instruments required :-

(1) 120 e. c. syringe for injeeting serum.

(2) 1 small glass bottle for pouring serum into from large bottle in order to fill syringes. 
(3) I small open vessel for carbolic aeid solntion.

(4) 2 clinical thermometers.

(5) 1 bottle containing 5 per cent. carbolic acid solution.

(6) cotton wool.

(7) 1 cork-screw for opening serum bottles.

(8) 1 pair of scissors.

(9) 2 ropes for casting animals.

(10) 1 measuring tape.

\section{Hcemorrhagic Septicamia Serum and Vaccines.}

Lingard in 1905 prepared an anti-sermm against this disease by the intravenous injection into cattle of small quantities of broth culture of the specific organism. The serum was not of high potency.

In 1908-09 an investigation was made on the relative susceptibility of stoek to Hæmorrhagic Septicãmia, the most suitable neans of protecting animals against infection, and methods of preparing a serum of high potency and a suitable dead vaccine.

A serum was prepared by repeated subcutaneous injections into cattle of large amount of broth cultures containing the sediment from older cnltures.

This serum in a single dose protects for a month to six weeks. It is protective for all susceptible animals in dose of from 5 c. c. to 20 c. c.

The sermm is prophylactic only and possesses no curative properties.

A dead vaccine was prepared by the mixture of a 48 hours broth enlture and sediment from older cultures.

The immunity following the varcine is of somewhat longer duration than that conferred by serum. The protection, lowever, does not set in until abont four days after the vaccination. The sermm is recommended for use in actural ontbreaks where animals are exposed to immediate infection.

The vaccine is more suitable for use before the disease bas appeared in anticipation of a seasonal outbreak and of imported infection.

The dose of vaccine is 5 c. c. to $10 \mathrm{c}$. e. for all animals.

In dealing with this disease serum is used as in Anthrax to protect animals exposed to infection during the period the disease is prevalent or until the animals can be removed from the infeeted areas or the sonrce of the infection dealt with by methods of disinfection.

The vaecine is used in localities where the disease is seasonably prevalent. Inimals are inoeulated just before the time when ontbrealis are of usual occurrence, 
The following instructions are forwarded with all Homorrhagic Septicomia scrum and vaccine sent out from the Laboratory :-

\section{Serum No.}

\section{Instructions for Treating Bovines and Equines with H wiorrhagic Septic amia Serum.}

Prepared at the Imperial Bacteriological Laboratory, Muktesar.

$$
\text { By "Serum Alone" Method. }
$$

(1) The "Serum Alone" method is to be used only in actual outbreaks of Hæmorrhagic Septicæmia. It serves to protect animals from contracting the disease and thereby curtails the spread of the infection. The immmnity conferred by a single dose of serum is of short duration for not more than six weeks.

Consequently, if animals are subjected to infection for a longer period they should be re-injected.

(2) The serum is injected subcutaneously in the region of the shoulder and for this purpose, the hair should be clipped over a small area of abont 2 inches liameter, and the part washed with a 5 per cent. carbolic solution before introducing the needle of the syringe. After injecting the fluid withdraw the needle and place the finger or: thumb over the smail tumour made hy the injected serum and diffuse the fluid downwards into the surrounding tissues.

(3) The doses of sermu ire :-

For cattle according to size from 5 to $20 \mathrm{c}$. c.

For buffaioes..............20 c. c. and upwards.

For poines and mules......... from 5 to 20 c. c.

For horses.............20 c. c. and upvards.

(4) (i) Every precantion should be taken to thoroughly disinfect all instruments and hands, etc.

(ii) $A$ bottle of serum that has been opened should not be nsed after 24 hours. The remaining contentis should he discarded.

(5) The serum is not cuirative and shouid not be userl on animals already infected.

(6) Lisi of instruments required :-

(1) 120 c. c. syringe for injecting serum.

(2) 1 small glass bottle for pouring serum into from large bottles in order to fill syringes. 
(3) 1 small open vessel for carbolic acid solution.

(4) 2 clinical thermoneters.

(5) I hottle containing 5 per cent. carbolic acid solution.

(6) cotton wool.

(7) 1 colli-screw for opening selum lottles.

(8) 1 pair of scissols.

(9) 2 ropes for casting animals.

(10) 1 measuring tape.

\section{VACCINE No.}

Instruettons for T'reating: Bovintes and Equines wTth Hemorrha-

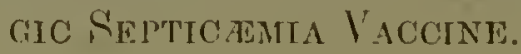

Prepared at the Tmperial Bacteriological Laboratry, Muktesar.

I. The dlose of the vaccine is from 5 c. c. to 10 c. c.; 5 c. c. for animals less than $600 \mathrm{lbs}$. weight and $10 \mathrm{c}$. c. for animals over that weight.

II. The vaccine is to be injected subcutancously with the usual aseptic precantions.

III. A slight swelling at the seat of inoculation may result and persist for two or three days, but the vaccine does not canse any other symptoms.

IV. The vaccine is a sterile product and is not capable of spreading infection or producing the discase in inoculated animals.

$V$. The immunity following the use of the vaccine is established in about four days, and persists for abnut two months.

VI. It should not he kept for longer than three months. It is requested that any vaccine remaining after this time be returned to the Laboratory for the purpose of retesting.

VII. The vaccine should not he used during an outbreak, as for-a perind of four days following the inoculation of vaccine the animal is still susceptible to the disease.

VIII. An anti-sernm can be supplied which gives an immunity lasting for about six wecks. This should be used, in actual outbreaks where animals are exposed to infection at the time of inoculation.

IX. For details of experiments conducted in the laboratory with the vaccine and anti-serum see the Indian Civil Veterinary Departo ment Memoir No. I.

$\mathrm{X}$. I bottle of vaccine which has been opened should not be used after 24 hours. The remaining contents should be discarded. 
XT. The nsual measures of disinfection and segregation should be carried out.

XII. List of instruments required:-

(1) 120 c. c. syringe for injecting serum.

(2) 1 small glass bottle for pouring serum into from large hottles, in order to fill syringe.

(3) 1 small open vessel for carbolic acirl solution.

(4) 2 clinical thermometer's.

(5) 1 bottle containing 5 per cent. carbolic acirl solution.

(i) cotton wool.

(7) 1 cork-screw for opening serum hotties.

(8) 1 pair of scissors.

(9) 2 ropes for casting animals.

(10) 1 measure tape.

\section{Charbon symptomatique or Black Quarter.}

The well known system of vaccination against Charbon Symptomatique discovered by Arloing and Comevin has becn in practice in India since 1906.

The objections to the use of this vaceine in India are, that at times a large number of deaths oceur after the use of either the first or the seeond vaccine; and also the necessity of two operations at an interval of several days combined with the danger of contamination of the vacrine during the process of manipulation.

Duling 1908-09 a series of experiments were carricd out to determine the method of vaccination safest and most easy of application to the cattle of this country.

A vaccine was prepared consisting of a mixture in fixed proportions of a first and second vaccine. These two vaccines werc attenuated soniewhat alter the method of Arloing and ('ornevin. The tests of this vaccine gave good results, no mortalities occured after inoculation and a strong immunity against the disease was conferred.

The vacrine is made up and issued in form of a small pillnle which is injected under the skin by means of an automatic pillule injector which was designed for this purpose at the Iaboratory.

Since 1908, 62,360 of this pillule have becn issued and used in the district with successful results. 
Black Qnarter is generally prevalent in certain localities and makes its appearance seasonally dnring the rains. Animals in infected localities should be vaccinated each year' as the immunity lasts for about sis to twelve months.

After inoculation immunity to the disease is not established for eight to fourteen days. Consequently animals exposed to immediate infection should not be vaccinated.

An anti-serum has been prepared in the Laboratory. This gives immediate protection but of short duration for ten to fourtecn days only.

The following instructions are sent with each issue of vaccine :-

\section{Blacklegons No.}

Manufactured at the Imperial Bacteriological Laboratory, Muktesar.

(1) The pillules should be injected subcutuneously behind the shoulder and for this purpose the hair should be clipped over a small area and the part washed with an antiseptic solution before introducing the needle of the Injector.

(2) The standard dose is I pillule per animal.

(3) The immunity is established alter ten to twelve days from the date of injection.

(4) The pillules should not be nsed during an outbreak as for some day's after its injection the animal is more susceptible to the disease.

(5) In any case care must be taken that ammals to be inoculated are not snbjected to infection for eight to ten days after vaccination, and stalls and byres should be thoronghly disinfected before proceeding with the operation.

(6) The following description of the automatic Pillnle Injector will be found very useful in its manipulation in the fielel.

\section{Descripution of in Aulomulic Pillude Injector.}

This instrument was devised for the pmrpose of injecting the vaccines in pillule form. It is simple and easy of manipnlation and does not readily break or' get out of order. 'l'he parts of the injector are :-

(A). A short steel rod.

(B). A sheath fitting over bhis red ant provided with a circular finger rest.

(C). An ejector pin.

(D). A large hypodermic needls. 
The $\operatorname{rod} A$ is provided with a button at the top. The lower end is hollow and is groved for the hypodemic needle to be sciewed on.
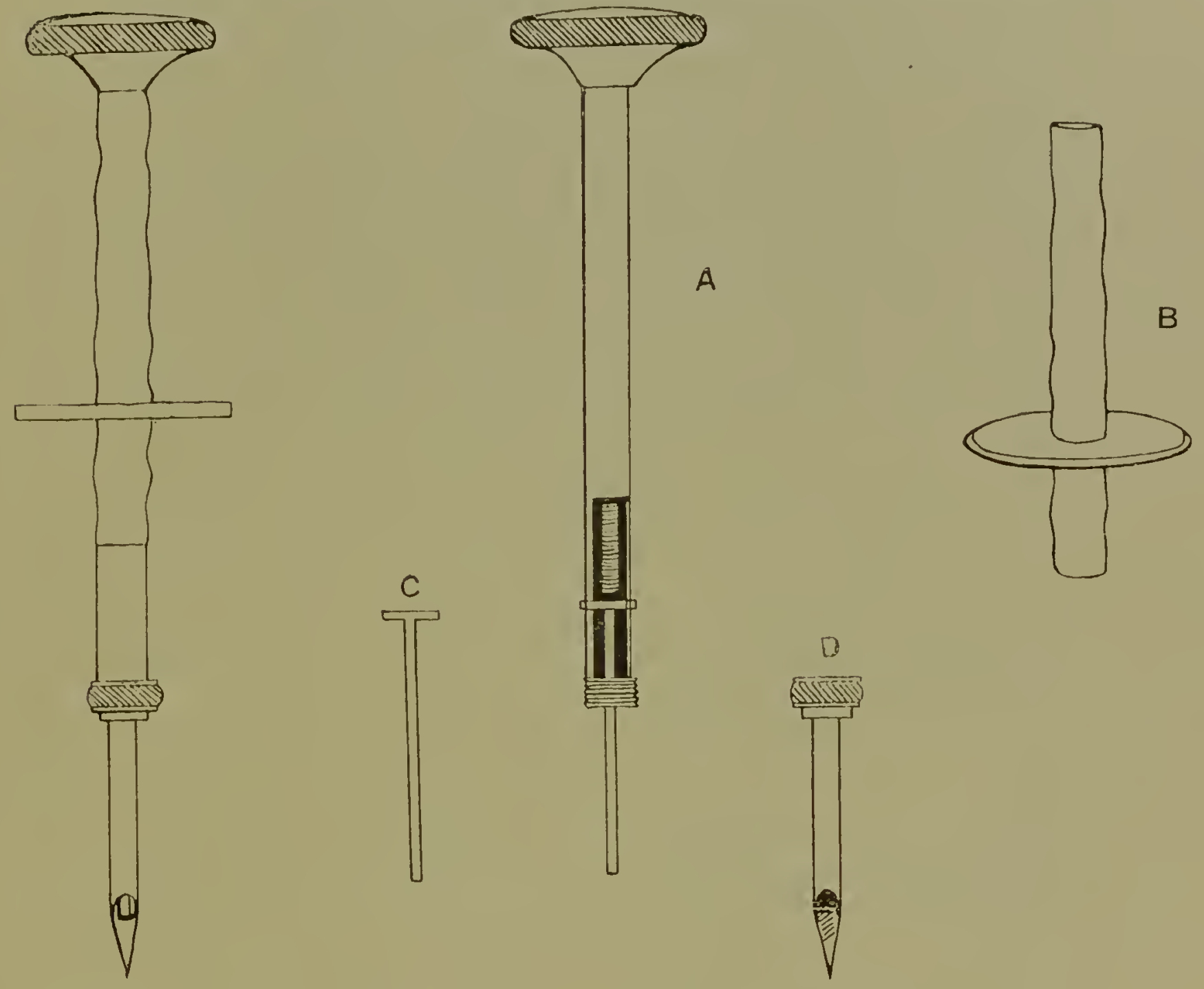

E

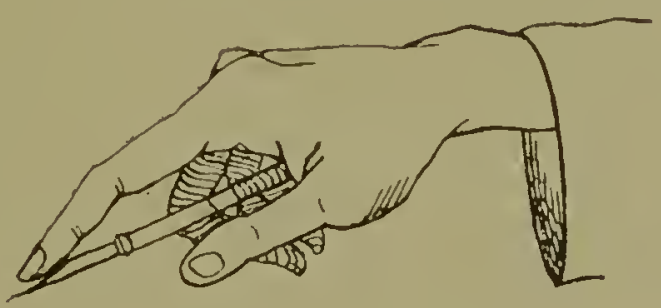

Above this is a channel to accommodate the head of the ejector pin. Working on the head of the ejector pin is a spiral spring. 
The sheath fits over the steel rod. and the end of the head of the ejector pin is fastened into the lower end of the sheath. At the lower third the sheath is provided with a circular finger rest. By means of the spiral spring the sheath has a play of somewhat less than $\frac{1}{1}$ inch along the rod.

Method of use.--By placing the button of $A$ in palm of the liand and the second finger on the rest of $B$, the rod is lowered in the sheath and the needle projects below the ejector pin. The pillule is dropped into the needle and the mouth covered by the first finger, ligig. (E). A fold of skin is seized by lingrer and thmmb of the other hand and the needle is inserted about hiblf an inch. 'The pressure on the button of $A$ is relaxed by which the rod is raised on the sheath and the month of the needle brought to the level of the ejector pin. By this action the pillule is forced out of the needle and the ejector is withdrawn.

\section{Mallein.}

Mallein is prepared after the usual method. Fach brew of Nallein is tested for reaction on one or more Glandered ponies. It is also tested for sterility on guinea pigs.

Brews giving double reactions are diseontinued. About 16,000 doses of Mallein are issued each year.

\section{Directions for using Mallein.}

\section{Dose.}

1. The dose of Mallein is one cubic centimetre or 18 minims. In retesting doubtinl reactions, especially in mules, a clouble dose should be used.

\section{Melhod of Operation.}

2. The rectal temperature of the animal should be taken and recorded twice, morning and evening, on the clay before the test is applicd.

The animal should be left at rest in the stable and protected from the sun and from winds. The most suitable time for the test is in the evening between 6 and $8 o^{2}$ elock after the heat of the day is over. The best form of syringe is one with asbestos piston as the whole instrument may then be sterilised by boiling it in water for five minutes before use. Clip with a seissors the hair from an area of about 5 inches square on the neek midway between head and shonlder, wash with soap, dry and sterilize with earbolic or other antiseptic. 
3. The Mallein must be injected into the snbentancous tissue about the eentre of the elipped area. Care must be taken that the full amount is injerted and that it is not introduced into the skin or muscles. Also that all instruments and the hands of the operator have been disinfected. Avoid the use of needles of large calibre.

\section{Temperalure Reaction.}

4. The temperature must be taken at the time of injection and the 9th, 12th and 15th hours alterwards. Delibyed reactions, where the thermal rise appears as late as the 24th hour, are not uncommon in India. Consequently, if no reaction has been observed at the 15th hour, the taking of temperature should be continued for this tine.

5 . A rise of temperature of $2^{\circ} \mathrm{F}$. from normal is considered an undombted thermal reaction. When the temperature is $102^{\circ} \mathrm{F}$. or more at the time of injection the temperature reaction is not a reliable test. In non-Glandered horses the temperature remains mafiected.

\section{Locul Reaclion.}

6. In glandered lorses a swolling appears at the site of inoculation within 24 hours, increasing in size to 36 hours, and persisting until the third or fourth day after inoculation. 'The swelling is fairly firm, with raised edges, painful to the toneh and in undoubted cases measuring from 5 to 10 inches in dianeter.

In horses that are not glandered a swelling may appear at the site of inoeulation. It is small, flabby, attains its maximm size during the first 15 hours and by the 24 th hour it has ahnost entirely disappeared. Its maximum diameter is usually about 3 to 4 inches.

7. When both a marked thermal and local reaction are manifested the hor'se is undoubtedly glandered. In India, especially in the case of mules frequently either the thermal or local reaction does not oceur or is little marked, and diagnosis has to be made on the characteristics of one reaction. The local reaction is a better guide than the thermal one in India.

8. Horses giving double reactions should be retested in not less than three weeks after the applieation of the first test.

9. The Mallein should be kept in a cool place and protected lrom light. Should it lose its transparency or become cloudy it must not be used. 


\section{Directions for opening the tubes.}

Seratch the tube with a fine fite about one-thisd of an inch from its narrow sealed end, and then break off the point by slight lateral pressure. Introduce the needle of the hypodermie syringe and withdraw the contents by suetion.

\section{Surre.}

In 1908 a sueessful method of euring Surra in lorses was discovered at the liaboratory. A large number of horses and mules suffering from Surra, either experimentilly inoenlated or naturally contracted lave been suecessfully treated at the Laboratory.

Horses and mules have been eured by means of :-

(1) Arsenie alone.

(2) Arsenic and Atoxyl.

(3) Arsenie, Atoxyl and Tartar Emetic.

(4) Salversan Alone by one or more injections.

Dogs have been eured by Salvarsan.

Full details of the experiments and methods of treatment are given in the Publications on Surra (see page 14).

The following instruetions are issued as a gruide to the doses and methods of administering Arsenie.

Copy of leller No. 1513, dated 1st October 1909, from the Imperial Bucleriologist, Mulitesur, to the Inspector General, Cinil Velerinury Departmenl.

In reply to your offiee letter No. 1701-351-11., dated 20th September 1909, I have the honour to forward instructions for earrying out a eurative treatment for Surra. This treatment is simple and has been effective in our experiments. Fight out of ten animals treated recovered and have shown no relapse.

2. A second system of treatment has been tested on a large number of eases and has given very suecessful results, but is not so simple as the first.

3. I am preparing a paper giving full details of all our experiments.

4. At present we have 32 eases enred and under observation from five to fifteen months without relapse, and about 20 other cases which have been under observation for shorter periods. 


\section{Rules for Surra I'reutment.}

I. Solutions of Atoxyl should be freshly prepared before use in distilled or boiled water. 'The water should be allowed to cool before the solution is made. Carbolic Acid should not be used for sterilising as it decomposes the Atoxyl. The solution is to be injected subcutaneously with the usual aseptic preeantions.

The Atoxyl by itself has no eurative effeet, but exereises a rapid action in elcaring the eireulation of mature trypanosones. It is, therefore, used only when trypanosomes are present in the cireulation. 'The use is indieated at the commencement of treatment. If the first dose does not result in the eomplete disappearance of trypanosomes from the blood on the following day, a second injection of $A$ toxyl should be given 21 hours after the first dose. Atoxyl should be kept in the dark. The Atoxyl and Arsenic should be given after feeding.

II. 'The injection of Atoxyl has to be followed by ten doses of Arsenious Acid in ball. Care must be taken in making up the balls and in mixing the drug with the other ingredients.

The doses which have been determined for horses aceording to their weight are detailed in the three attached tables.

An interval of one day is allowed between eaeh dose.

The anount of Arsenious Acid is gradually increased. If after any dose the animal is dull or off feed, the next dose must be suspended till the symptoms have passed off. If after any doses the animal is off feed and uneasy and showing symptoms of colie, this shows that the animal eamot tolerate the amount of Arsenious Aeid in that dose, and treatment must be suspended till the animal has recovered and the next lower dose used and no further inerease in the following doses to be made. Animals showing symptoms of eolie are to be treated with opium, ellorodyne or other sedative.

Should trypanosomes reappear in the blood during treatment with Arsenic, Atoxyl should again be used to elear the circulation of the parasites after which the Arsenic is to be eontinued.

III. Daily examination of the blood should be made and the result recorded with the daily temperature in the observation eharts. After the completion of the treatment the animal should be kept under observation, the blood being examined daily (or at least twiee a week) for a period of two months. 
If a relapse occurs after the first conrse of treatment a second similar course should be given with slightly increased doses of Arsenic.

IV. Throughout the treatment the animal should receive a liberal diet and walking exercise.

This treatment in our hands has given 75 per cent. of recoveries.

V. If the animal is in a very advanced stage of Surra and in wcak condition, it should be treated with Atoxyl injection alone at intervals of three to four dayss and receive care and full dict mitil it has sufficiently recorered to stand the doses of Arsenic.

\section{Cobs.}

Body weight from 300 to 500 llus.

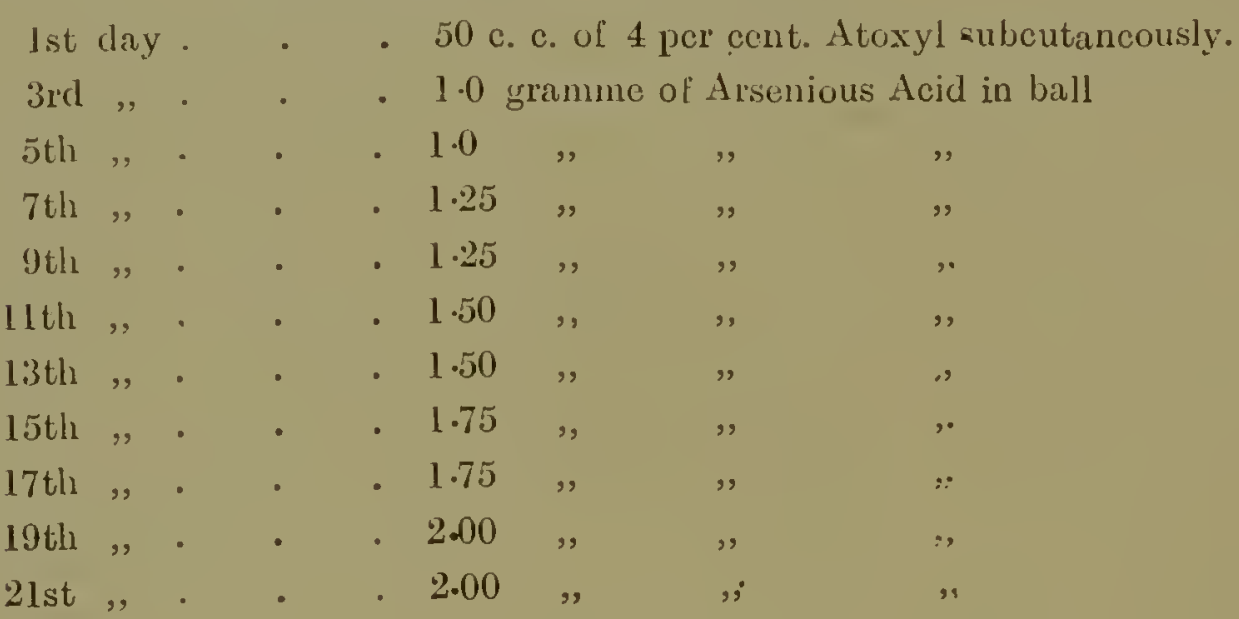

\section{Light Cavalry Horses.}

Body wcight from 500 to 800 lbs.

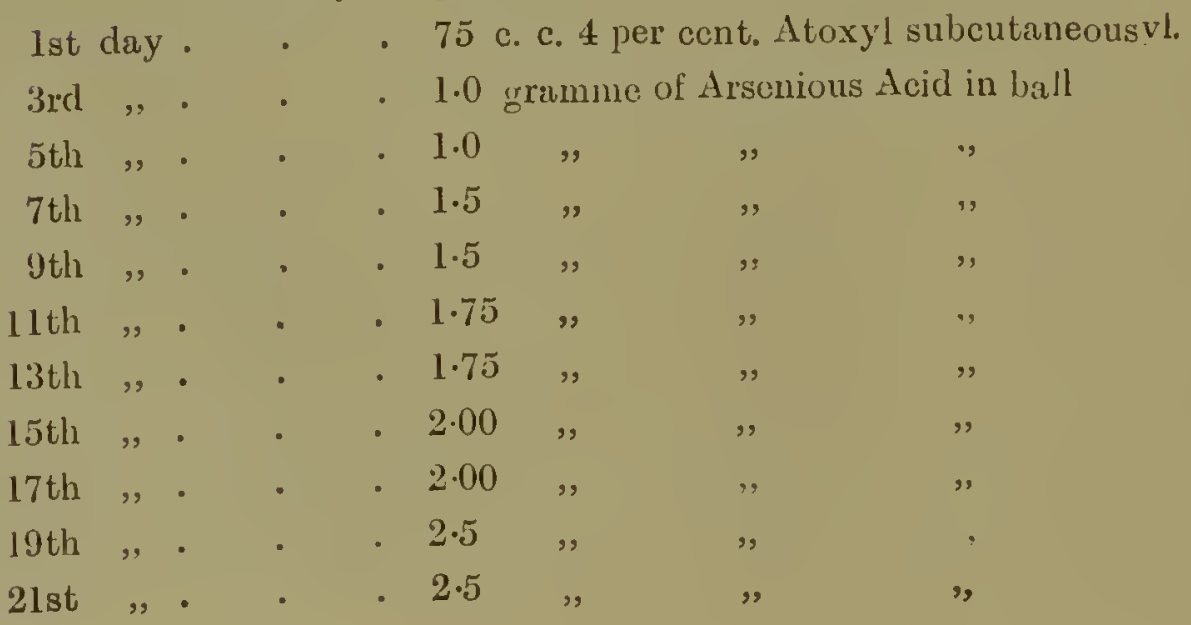




\section{Heavy Cavalry and Artillery Horses.}

Body weight from 800 to 1,000 lbs., and upwards.

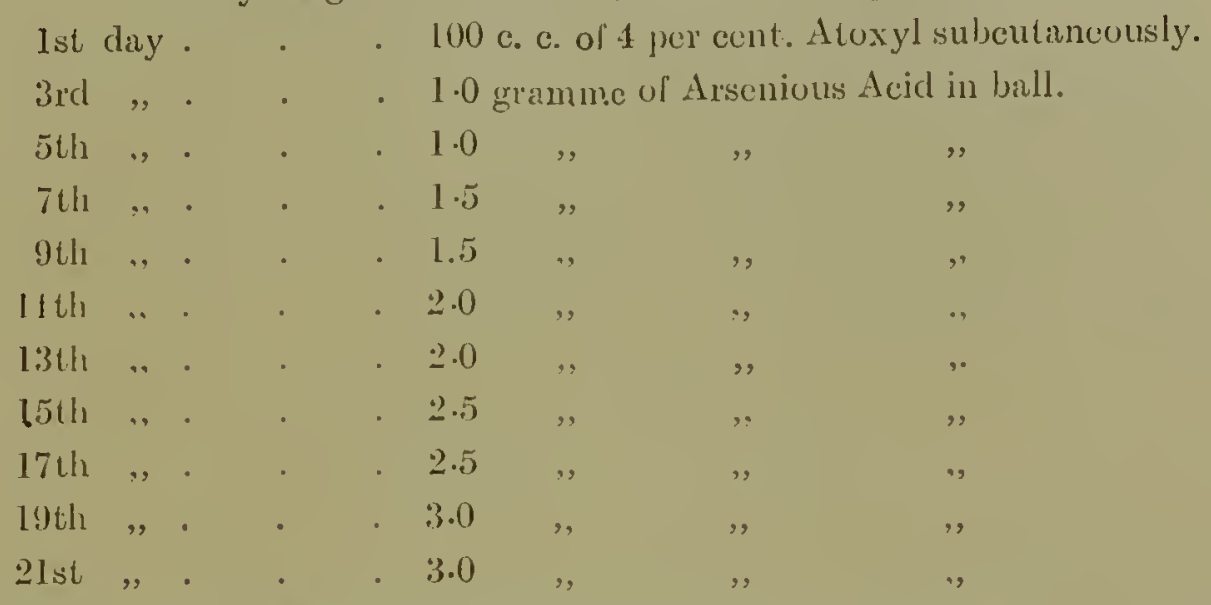

Remarks.-Large Mules will stand the treatment advised for heavy horses, and small mules the treatment for light horses, with the exception that a smaller dose of Atoxyl must be given.

fior large mules 61 to 75 c. c. of a 4 per cent. and

For small mules 50 to 60 c. c. of a 4 per cent.

\section{Anti-Streplococcic Serum.}

An anti-streptococcic serum is prepared by injections of broth cultures of Streptococcus of Stringles.

Horses, Ilules and cattle are used for the serun preparation. [njections are made both subcutaneously and intravenously.

The demand for this serum is small and up to the present it has been used only in the Army Remount Depots.

A vaccine on Baruchello's method was also prepared and issued for use to the Remount Depôts.

Favourable reports regarding the results of the Streptococcic antiSerum have been received.

\section{Tetrinus Anti-Toxin.}

Owing to very small demand for this anti-Toxin the preparation at the Laboratory has been discontinued.

Anti-Toxin for veterinary use can be obtained from Messis. Kemp \& Co., Bombay (Parke Davis Anti-Toxin) or from Messis. Smith, Stanistreet, Calcutta (Burrough and Wellcome Anti-Toxin). 


\section{T'uberculin.}

'Tuberculin for Veterinary use is prepared after the usual method.

Tuberculosis is not a common disease of stock in India and there is little demand for 'I'uberculin.

$\Lambda$ bout 344 doses are issued annually.

The following directions are forwarded witl all Tubereulin sent out from the Laboratory:-

\section{Directions for using Tuberculin.}

1. While under the tuberculin test cattle ought to be kept in the house, fed on their usual food, and protected from draughts. They ought not to be allowed to drink large quautities of cold witer between the 6th and 15th hours after injection. It is well to take their temperature at least once on the day preceding the test.

2. The dose of tuberculin for a medium-sized cow is 2 cubic centimetres, or 36 minims, and it may be varied above or below that aceording to the size of the animal. Large bulls ought to receive 4 e. e.

3. It ought to be injected under the skin with a clean hyporlemic syringe. The most convenient points are in front of the shoulder, or on the elest wall behind the point of the elbow. The best form of syringe is one with an asbestos piston, as the whole instrument may be sterilised by boiling it in water for five ninutes before use.

4. The tuberculin must be injeeted into the subcutancous conneetive tissue, and care must be taken that the whole dose is introduced.

5. The temperature must be taken at the time of injection, and at the 9th, 12 th and 15th hours afterwards.

6. Animals in which the temperature during the fifteen hours following the injeetion rises graduclly to 104 or more may be elassed as tuberculous, and those in which it remains under 103 as not tuborculous. When the maximum temperature attained is under 104 but over 103, the case must be considered doubtful, and the animal may be re-tested after a month.

7. The test is not reliable in the case of animals in the last stage of the disease, or in those in which the temperature is over 103 before injection.

8. The tuberculin should be kept in a cool place, and protected from light. Should it become turbid or cloudy it must not be used. 
9. The tuberculin test does not render the milk in any way injurious.

Seratch the tube with a fine file about one-third of an inch from its narrow sealed end, and then break off the point by slight

Direction for opening the lubes.

lateral pressure. While an assistant holds the tube vertieally, with its narrow end downwards, introduce the needle of the hypoderunie syringe just within the opening, and withidraw the eontents by suction.

\section{Examination of Specimens.}

Each year about 140 pathological specimens are forwarded to the Laboratory for the purpose of diagnosis and report.

The following directions are issued for collecting and packing naterial to Muktesar :-

Directions for the collecting and pacting of material to Muklesar for murpose of imestigation.

Blood, pus and olher fuid-should be forwarded either in sealed pipettes or as smear preparations on cover glasses or slides. In using the pipettes the following precautions are to be observed:-Both ends of pipette to be sterilized in the flame (spirit lamp), one end to be broken by means of a sterile forcepss and inserted in the fluid after which the other end is to be hroken. The fluid will then be drawn up into the pipette. Sonetimes it is necessary to aspirate but eare should be taken that fluid is not drawn into the month. After filling the pipette, seal hoth ends in the flame. Two or three pipettes should be filled and after carefully rolling in cotton wool, or other soft material be packed in a box and forwarded as early as possible.

To oblain blood from a living animal. - a vein in the ear can be punetured or an incision made into a musele. ('ure must he taken to wash the part and to sterilize with carbolic 5 per cent. or other anti-septic fluid (not corrosive sublimate). The part should be allowed to dry before making the incision in order that the blood nay not be mixed with any of the anti-septic. If blood is taken from an incision in muscle or skin pressure should not be exerted in the part, as, in this way an exeess of serum and few blood corpuseles are obtained.

In taking blood from a dead animal the most snitable metlod (execpt in Anthrax) is to expose the heart, and after sterilizing an area by apply- 
ing the heated blade of knife, insert the pipette through this part into the right ventricle of the heart.

In case of Anthrax the blood is taken immediately after death from vein of ear.

Snear preparations can be taken from any fluid aiso from organs as Liver. Spleen, etc. In such preparations care must be taken that the material is sterile and that the surface layer is as thin as possihle. Thick smears are useless. To take cover-glass preparations of hlood, or other fluid. a drop abont the size of a pin-head is to be taken on one cover-glass and immediately a second glass placed over this and allowed to rest for a secont, then drawn rapidly apart. No pressure should be exerted and in delay made. If the blood corpuscles are drawn out or fibrin depnsited on the glass, the preparations are useless. In the same method a preparation of fluid can be made on a slide hy smearing the fluid by means of the edge of a second slide or by means of a surgical needle. These preparations should be allowed to dry hefore packing. Wach slicle or cover-glass should be carefully labelled. Before using, care is to be taken that cover-glasses and slicles are clean.

Oryans. Tissues and Neoplasms, - should he taken, as fresh as possible, well washed in water and then placed in alcohol, rectified spirit, corrosive sublimate (saturated solution) or Formaldehyde (10 parts of the commercial Formaline to 90 parts water). Sectious of more than one inch square are not reçuired for microsicopical examination.

Culures.-Chlture tuhes are inoculated by means of the platinum wire or by use of pipettes. 'To take material from the interior of organs and tissues, the surface is first sterlized by searing it with a hot knife which has been heated in flane of spirit lamp and then a small incision is made with another hot knife in the seared or sterilized area. . The material from the interior is collected on the end of the platinum wire which has also been previously heated in flames. In the case of exudations care should be taken not to contaminate such fluid by handling before the material for culture has been obtained. The material is transferred hy means of the platinum wire to the surface of the culture medium, avoiding the brealing of the surface. The material should he in small quantity and be well distributed over the nutrient surface. A second tube should be inoculated from the first by touching the platinum wire, previously sterilized and cooled, on the surface of the first tube, and rubbing the infected wire over the surface of the second tube.

At post-mortems, cultures are made from heart, liver, spleen, lungs or kidneys. 
Culture tubes should be labelled after inoculation. Culture from the blood of the heart should be made before the removal of that organ from the body by searing the right ventricle and then puncturing it with a sterilized knife to admit the platinmm wire or the pipette. 'The amount of the blood used for the culture should be as much as will adhere to the platinum wire, or one drop from a pipette.

In order to prevent contanination of the culture media, the rubber cajs should not be removed till the tubes are required for use. After removing the rubber caps the mouth of tube is sterilized in flame and after inoculation of the media the cotton plug is slightly burnt in flame before being inserted again in tube. Before replacing the rubber cap after inoculation of cultures these should be sterilized by washing in aseptic solution.

In case of ('harbon Simptomatique as small piece of the infected muscle should be dried and placed in a sterile test tube without any antiseptic. 



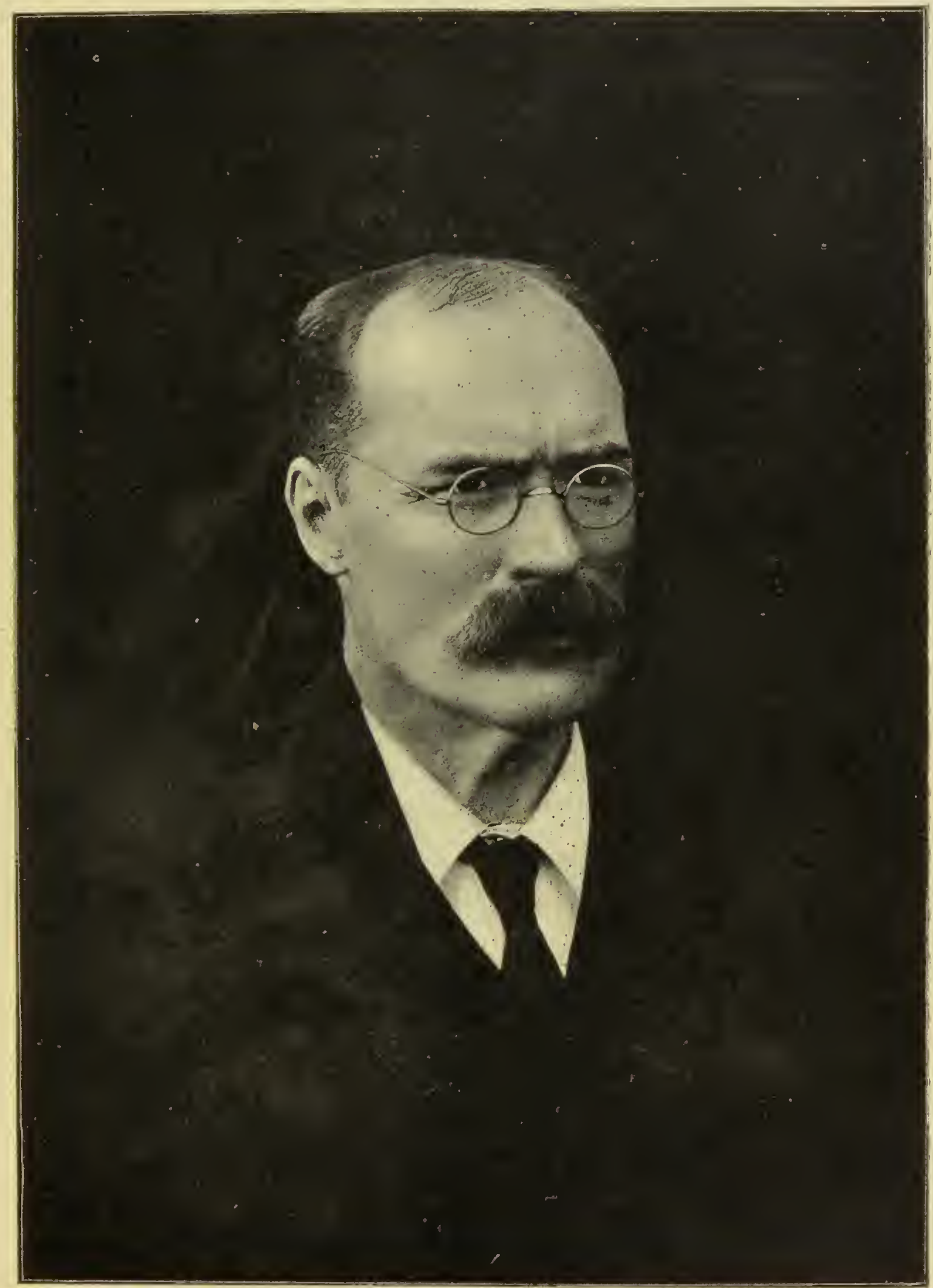

Dr. Alired Lingard. 



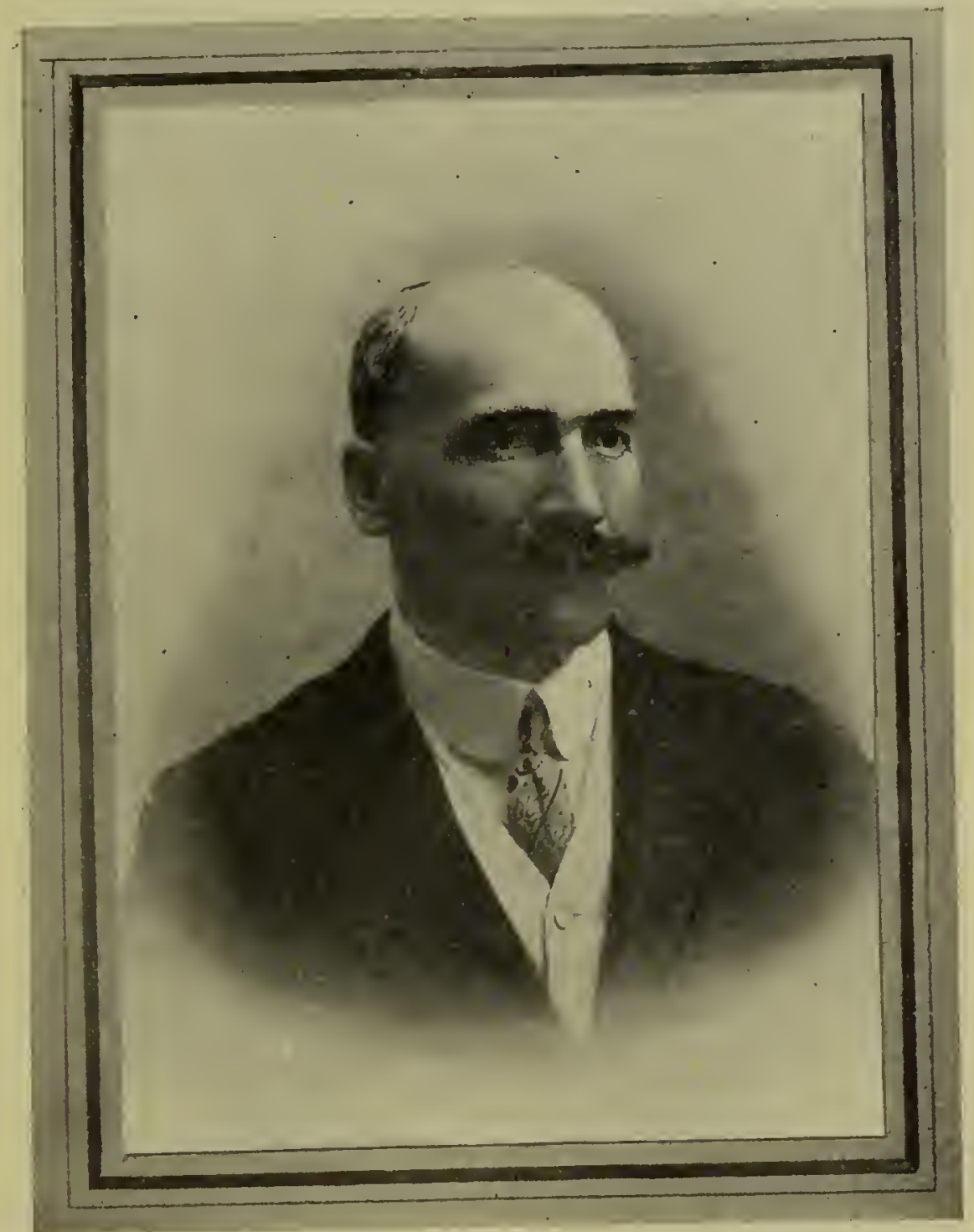

Jinjor J. D. E. Holmes. 



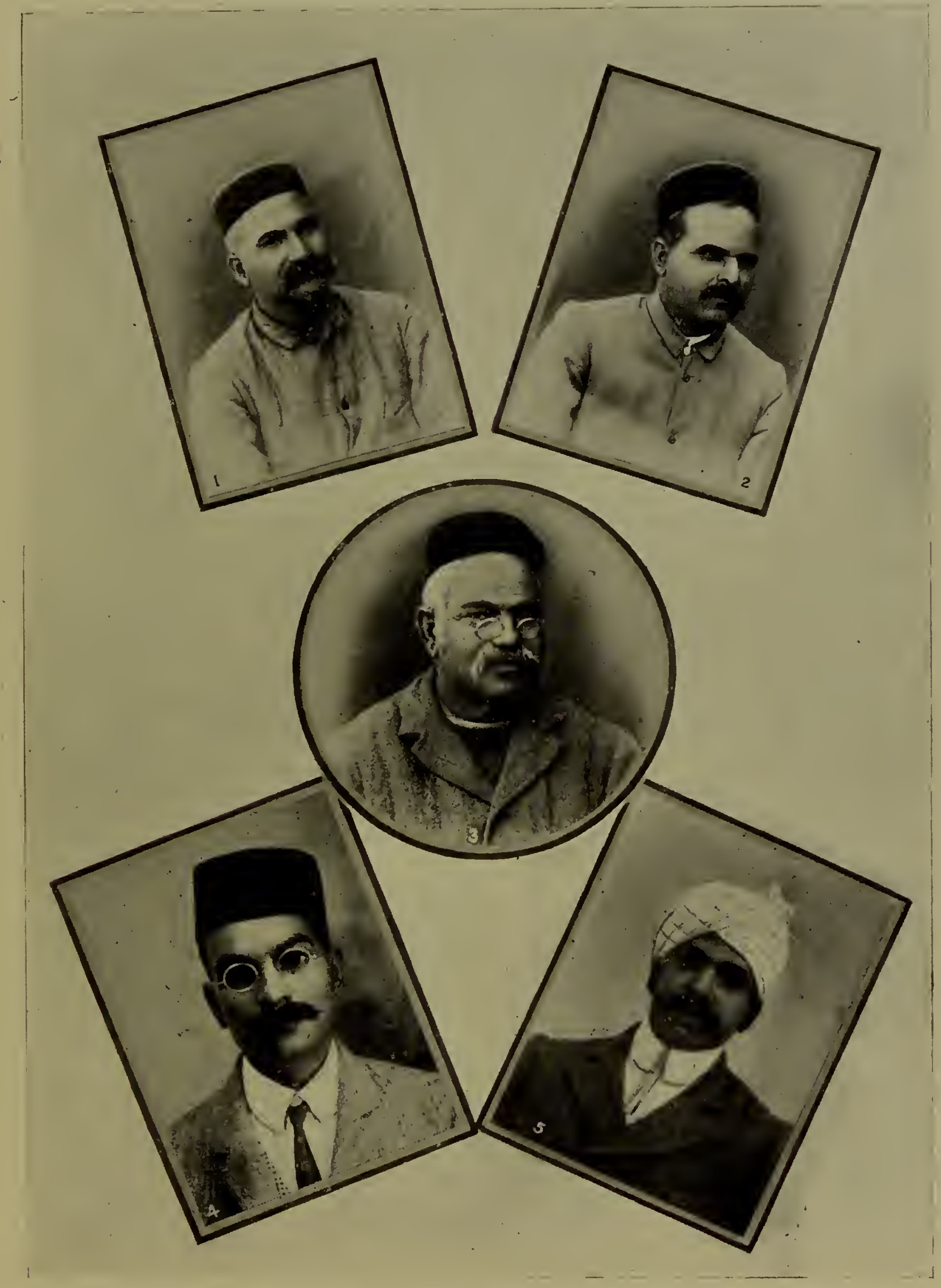

$\begin{array}{ll}\text { (1) Pt. Ram Datt. } & \text { (2) Pt. Krishna Nand. }\end{array}$

(3) Rai Sahib Pt. Nitya Nand. $\begin{array}{ll}\text { (4) B. Duni (hand. } & \text { (5) Khan Sahib B. Wazir Mohammad. }\end{array}$ 



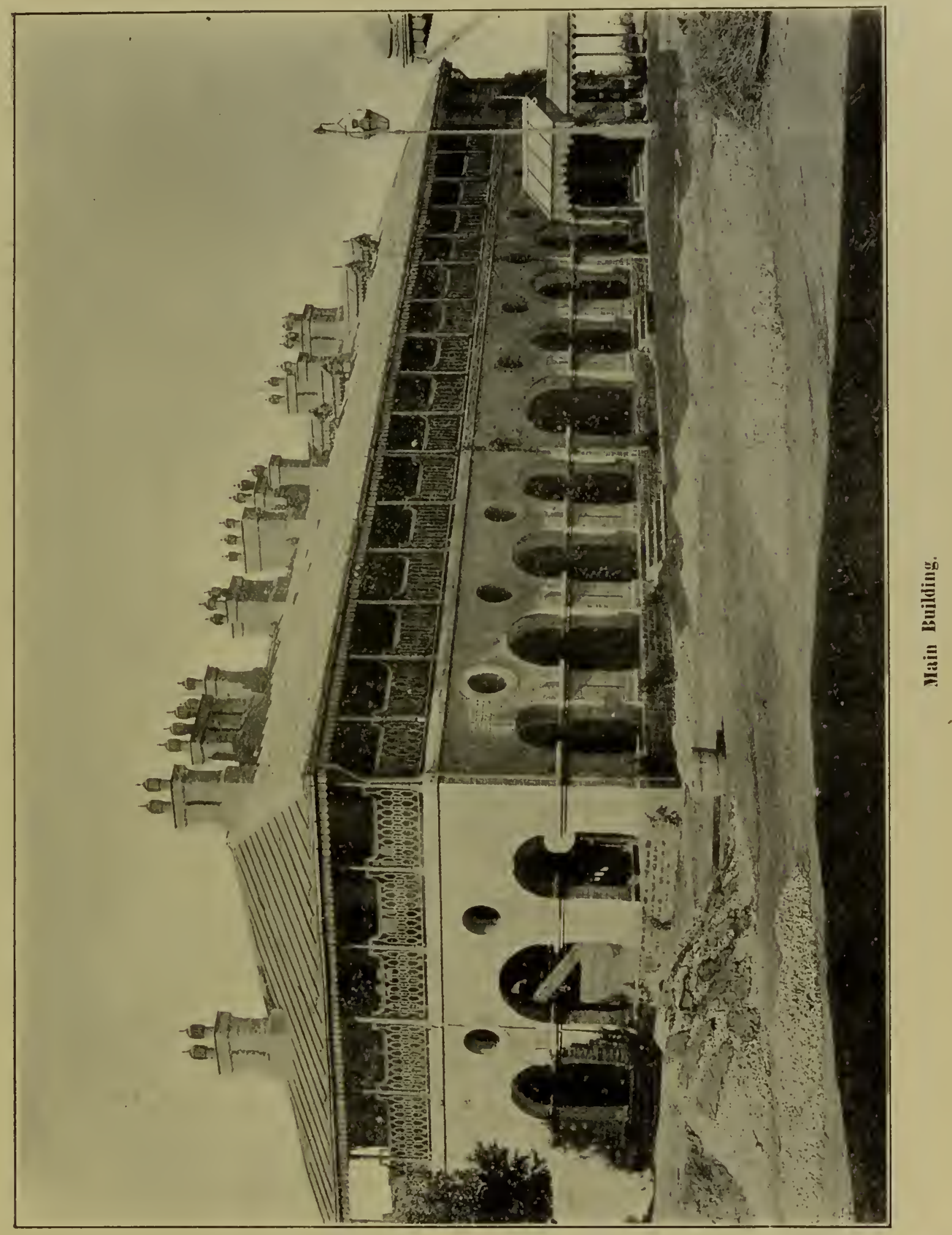





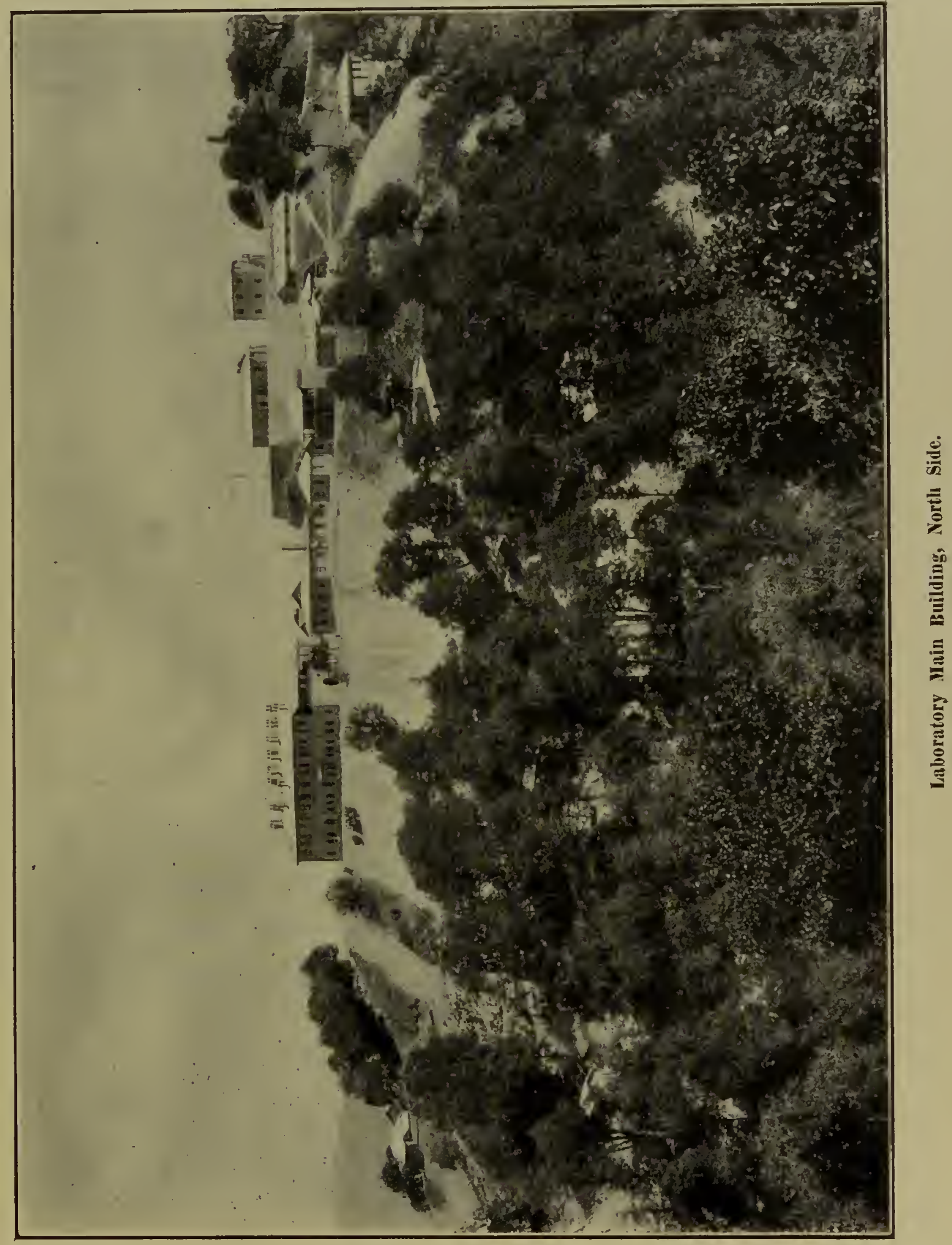





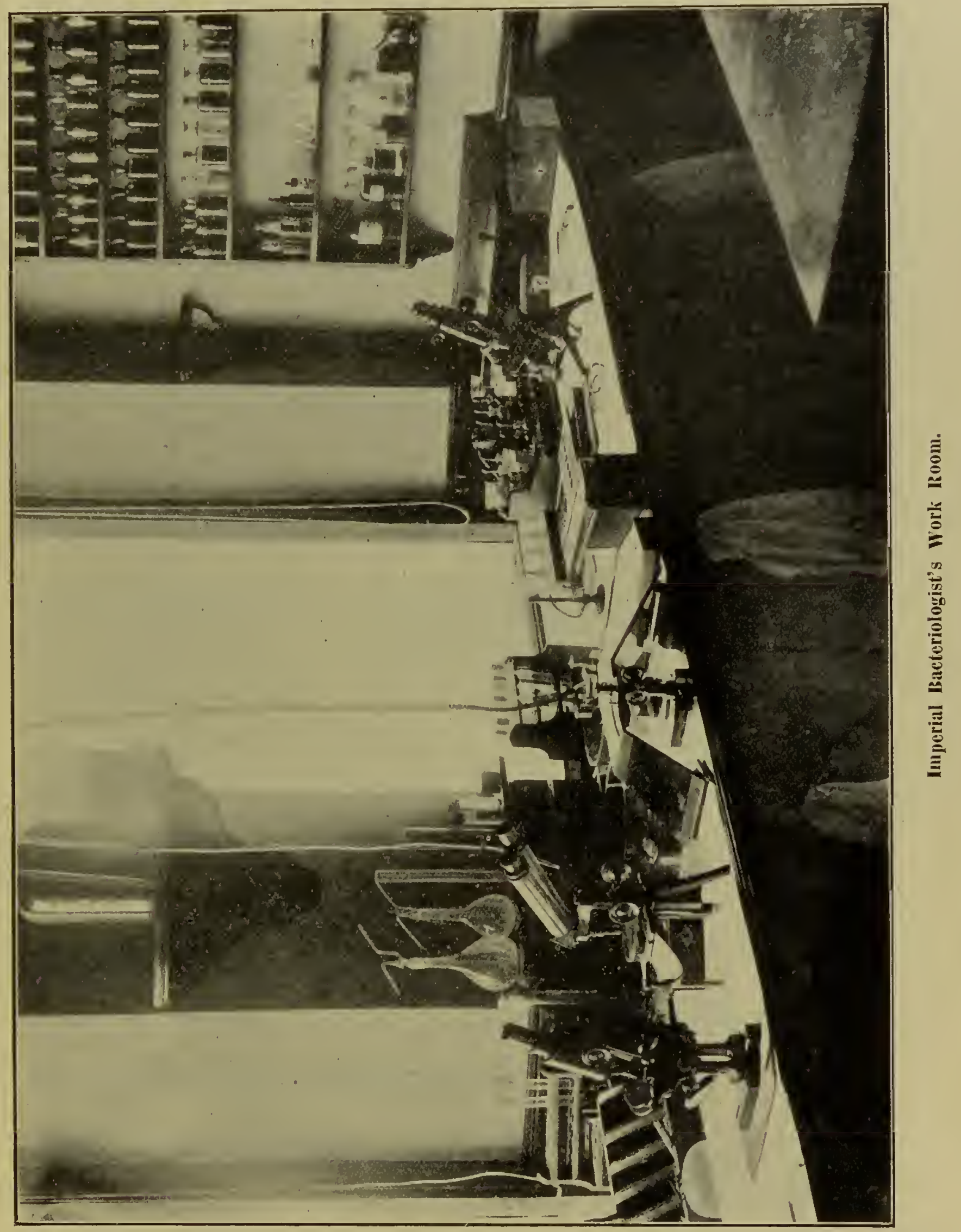





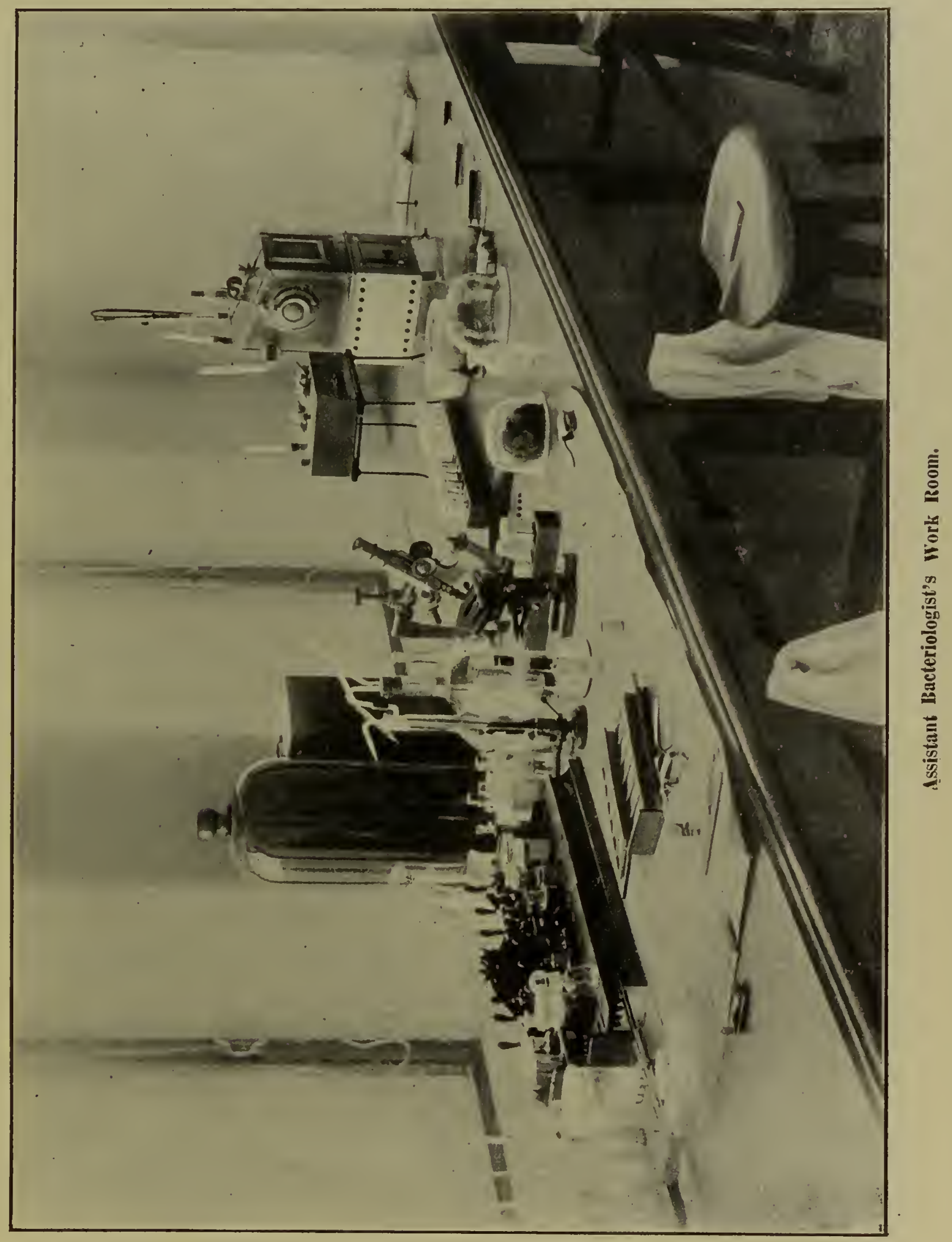





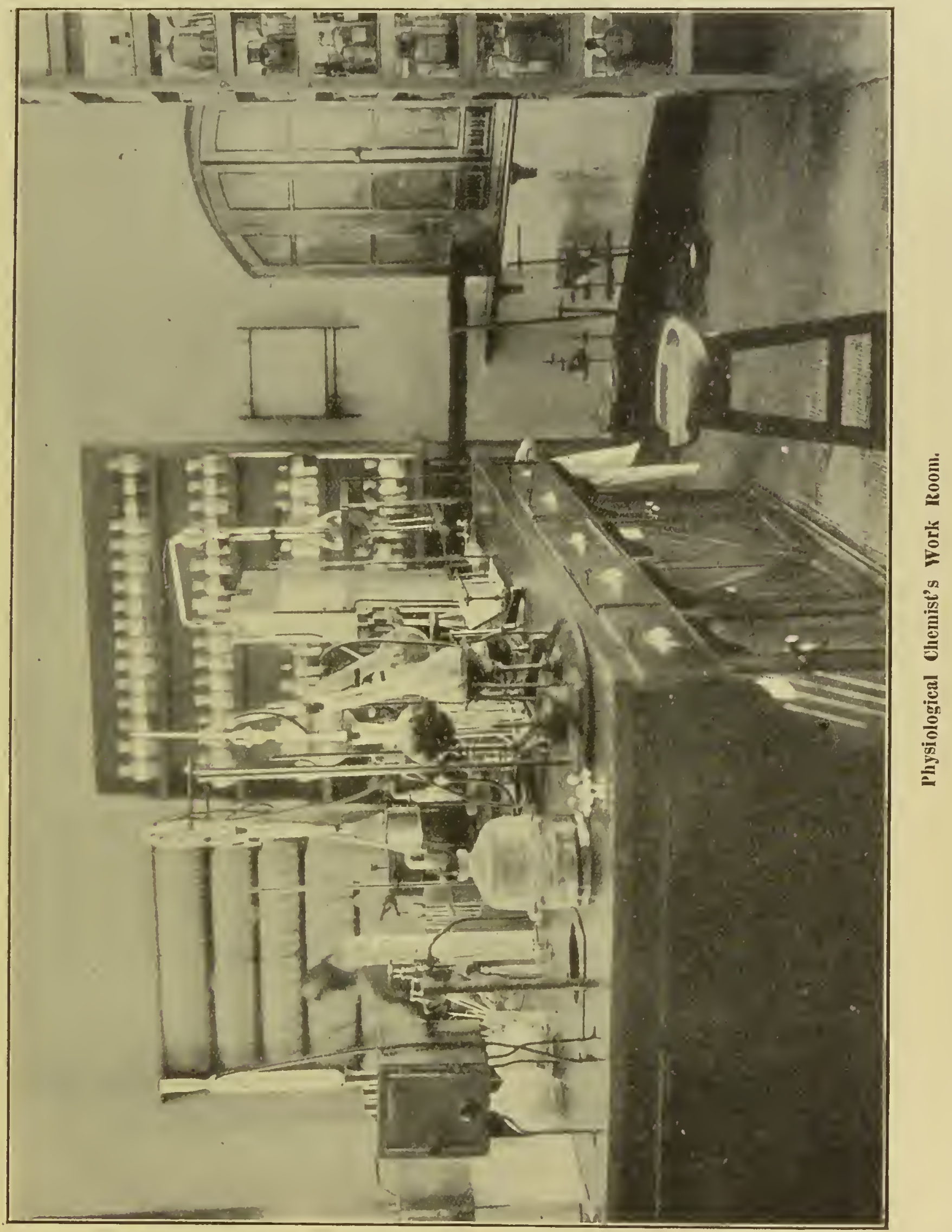





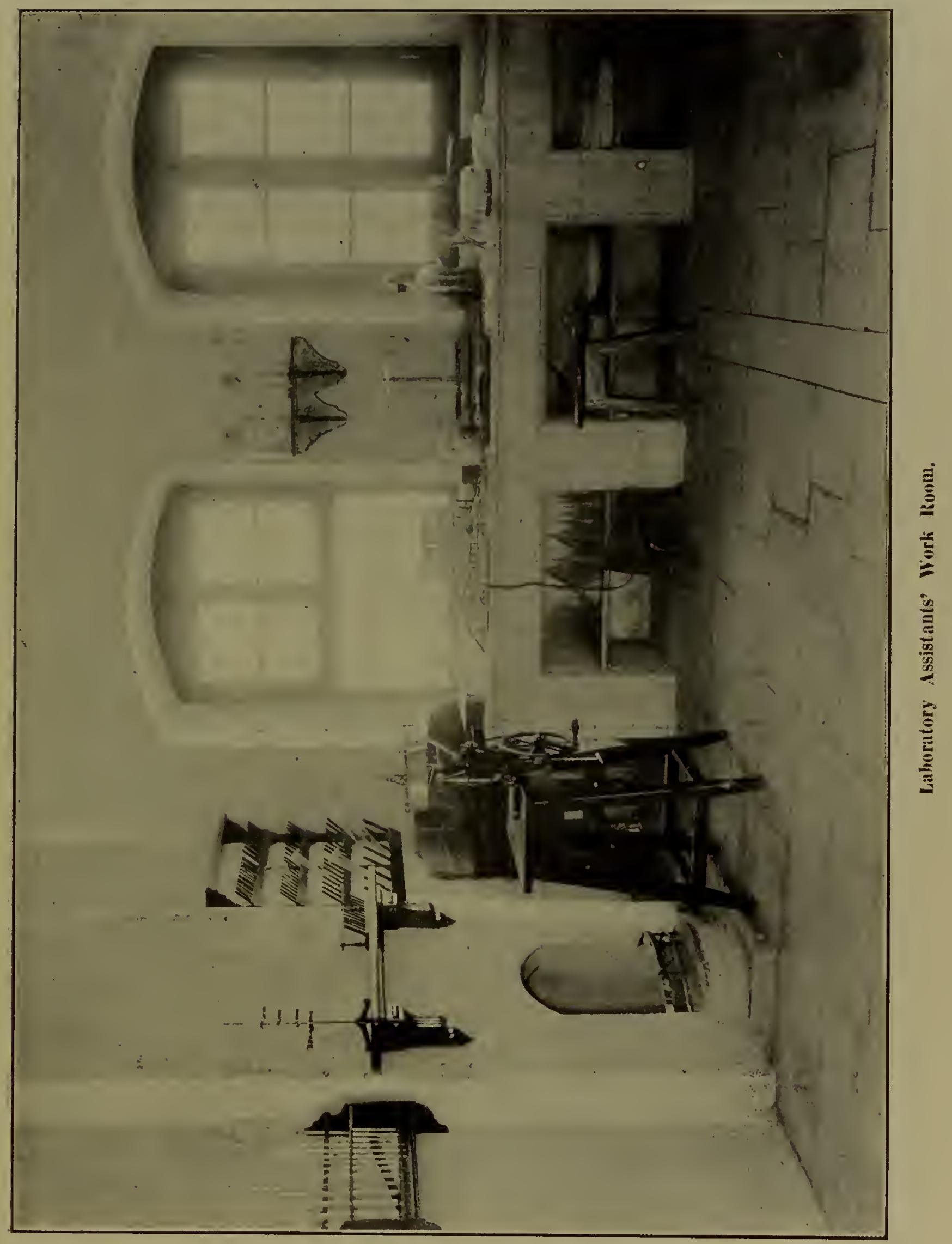





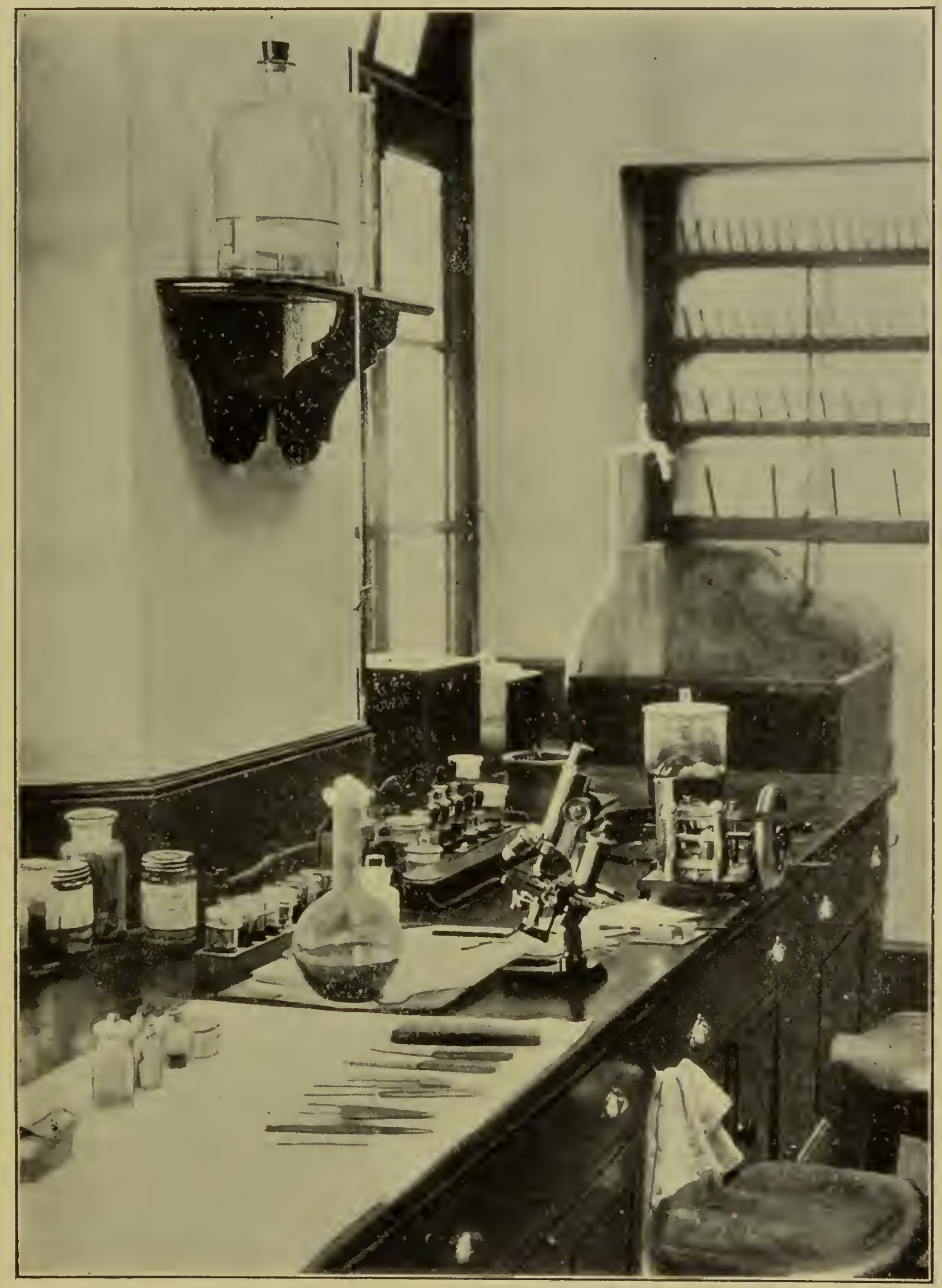

Hicrotome Room. 



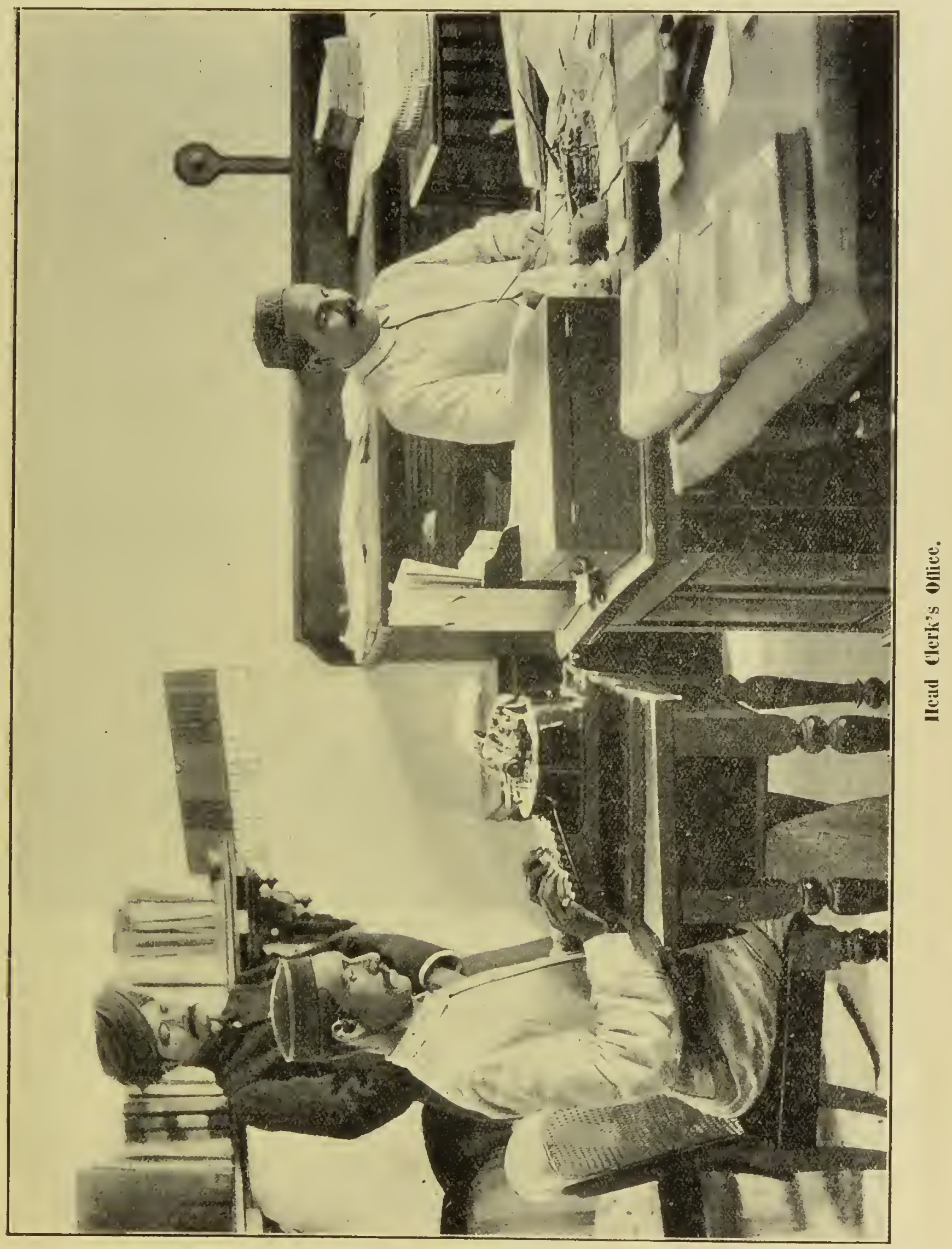





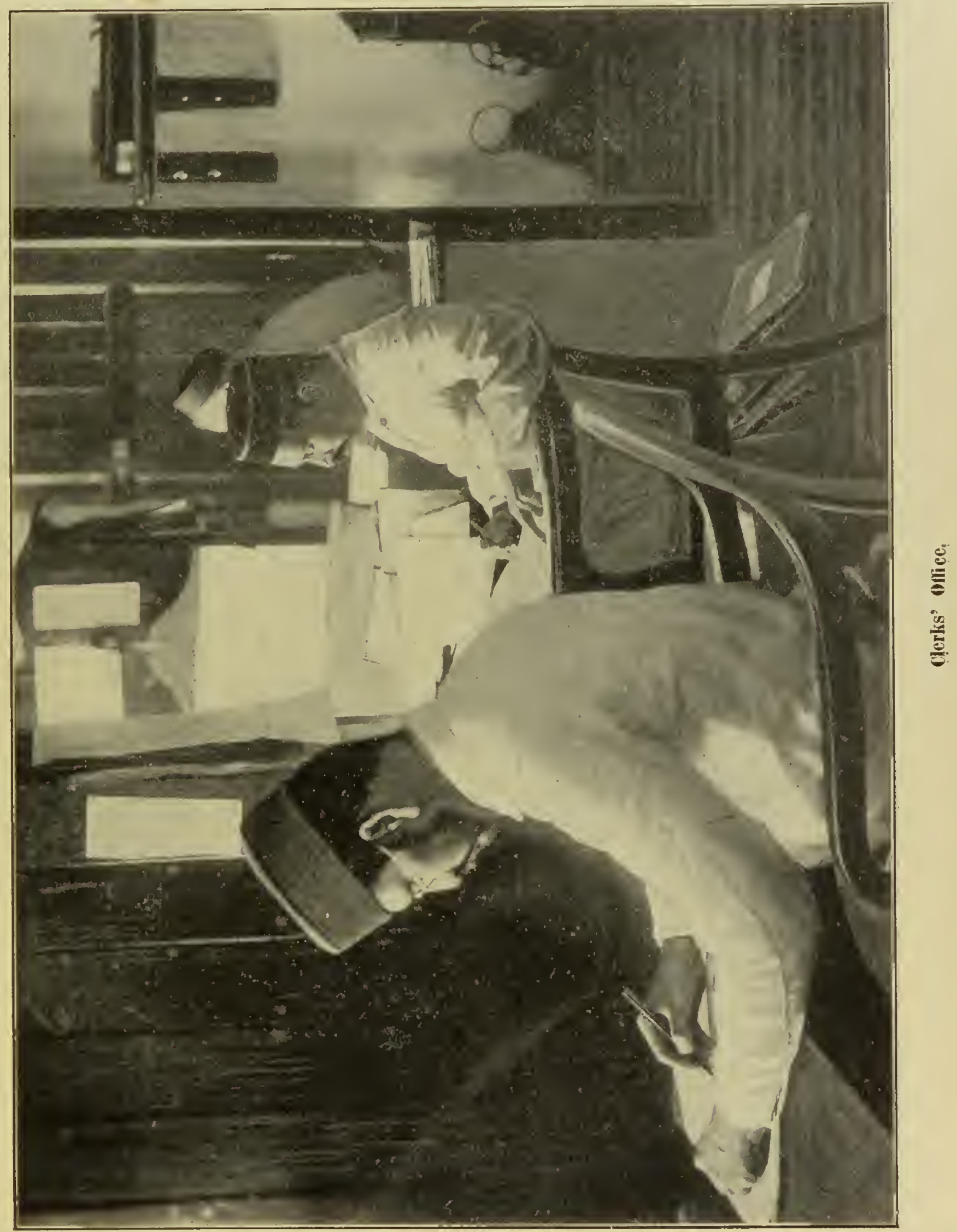





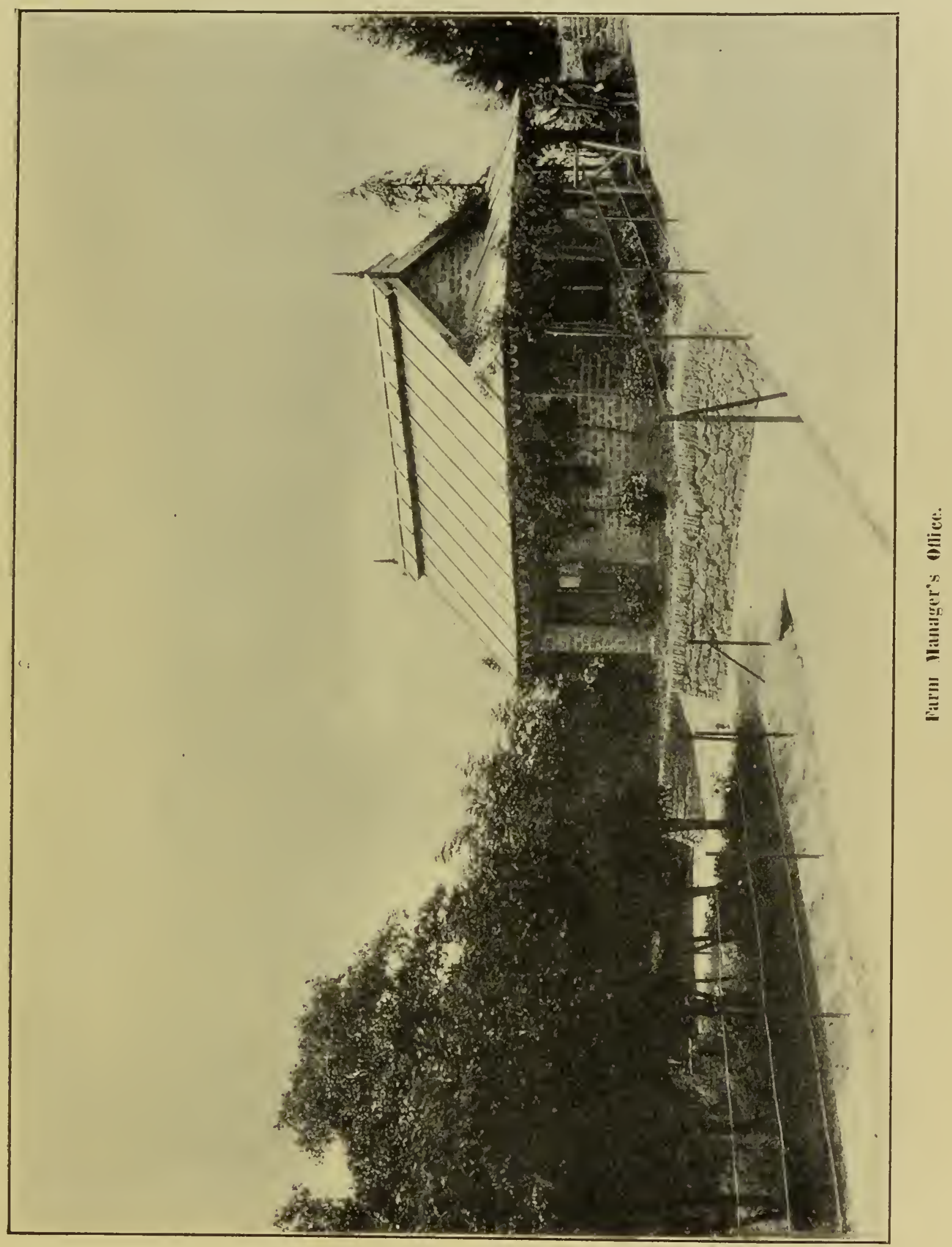





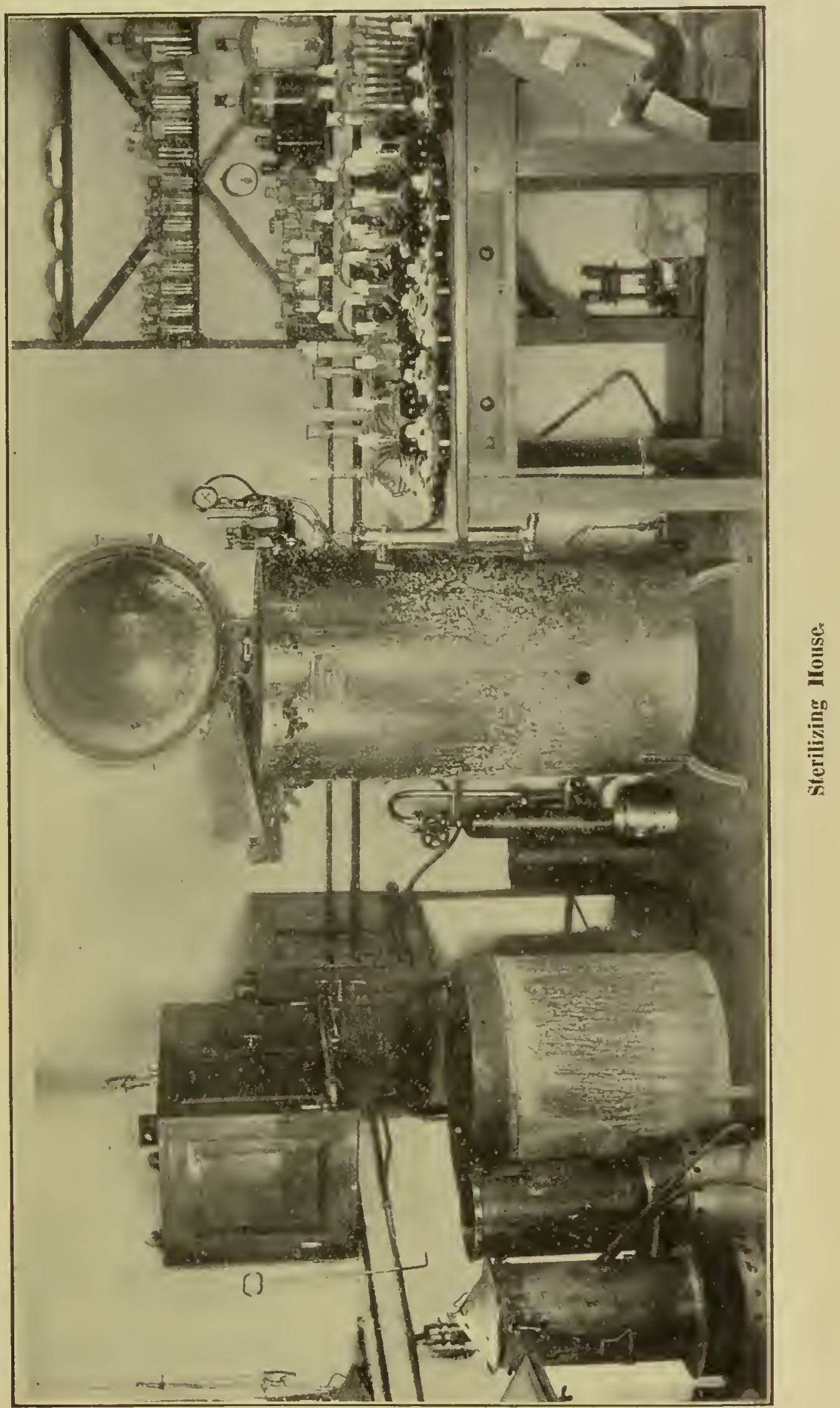





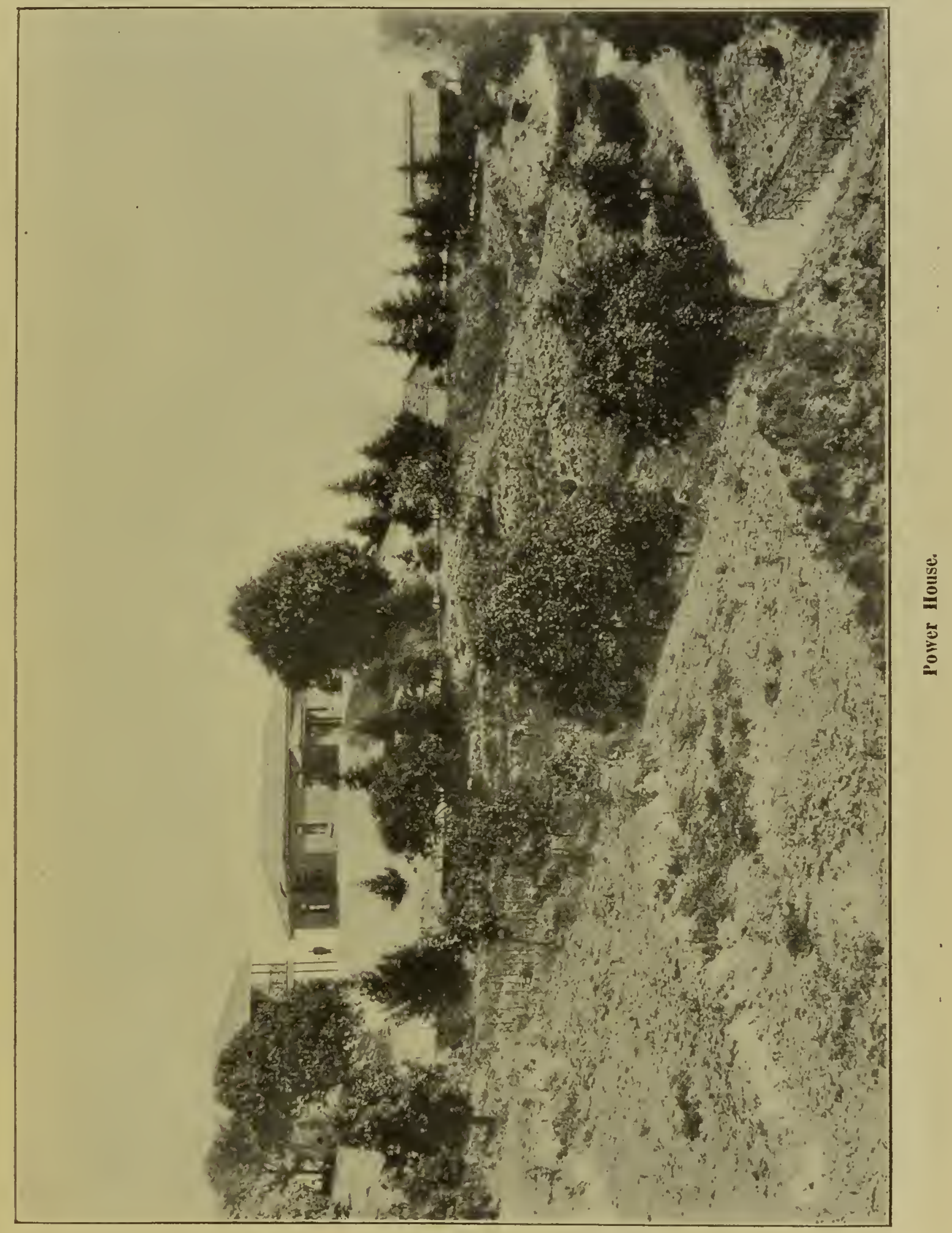





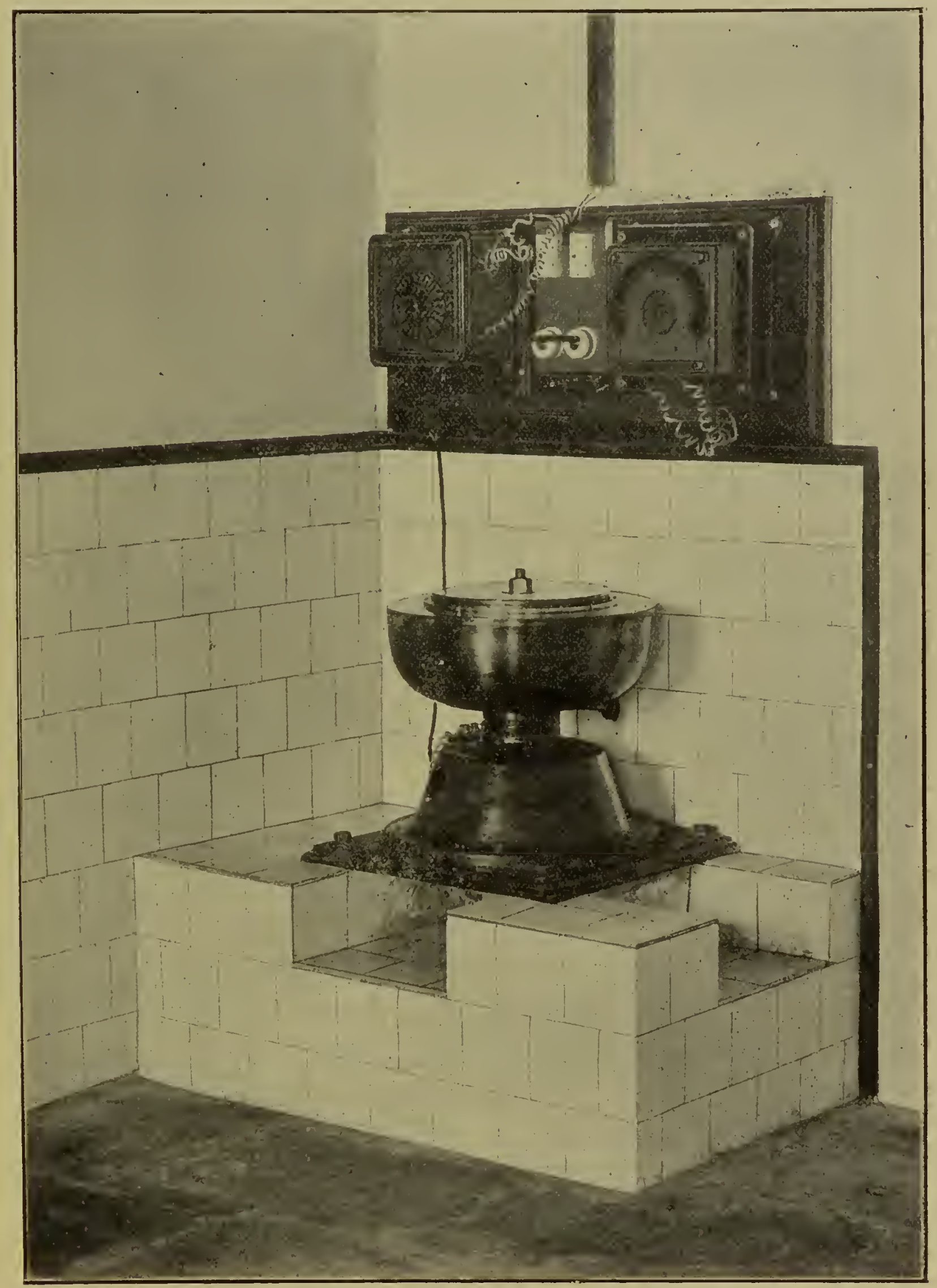

Wectric centrifuge. 



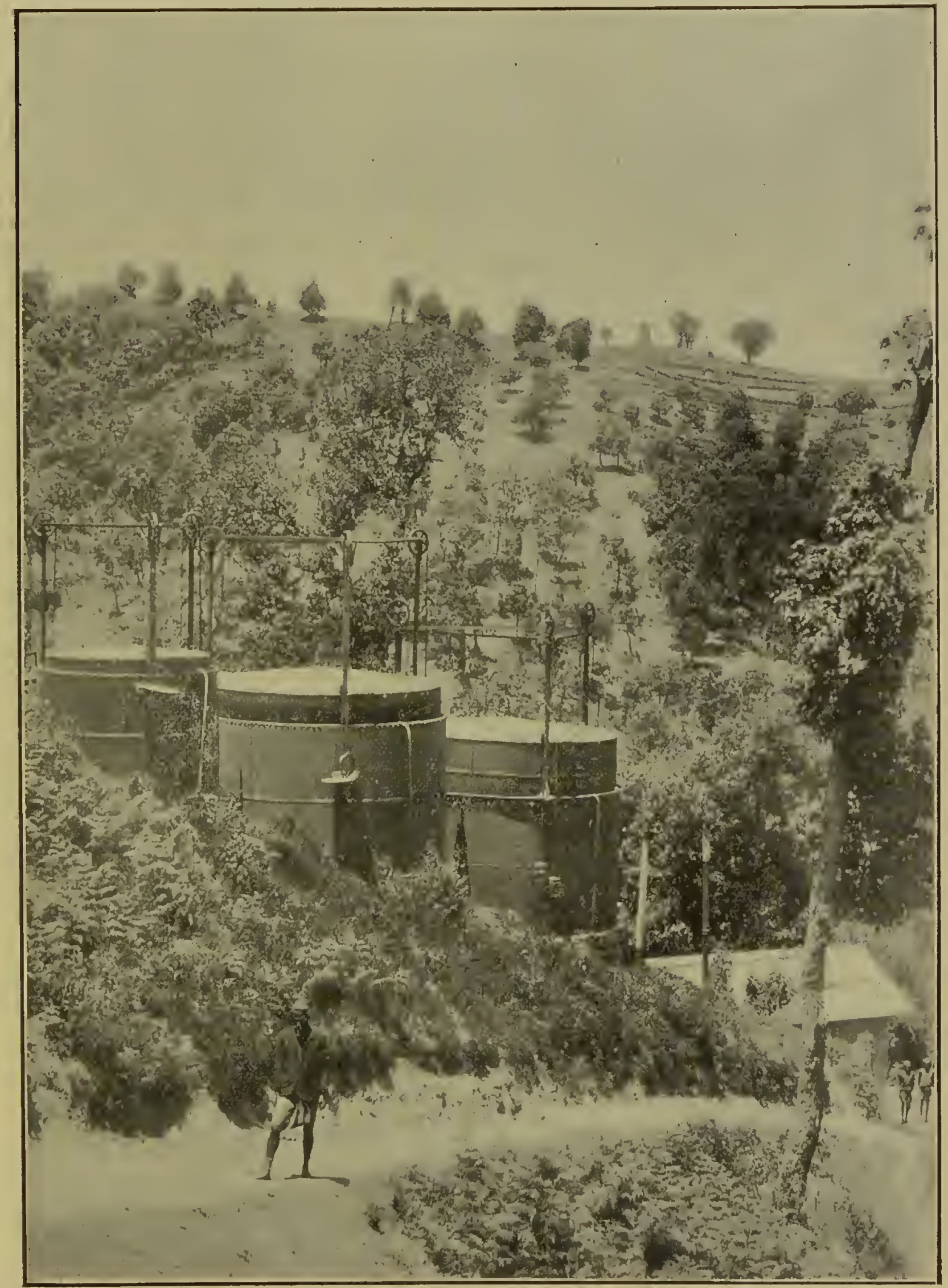

Gas Works. 



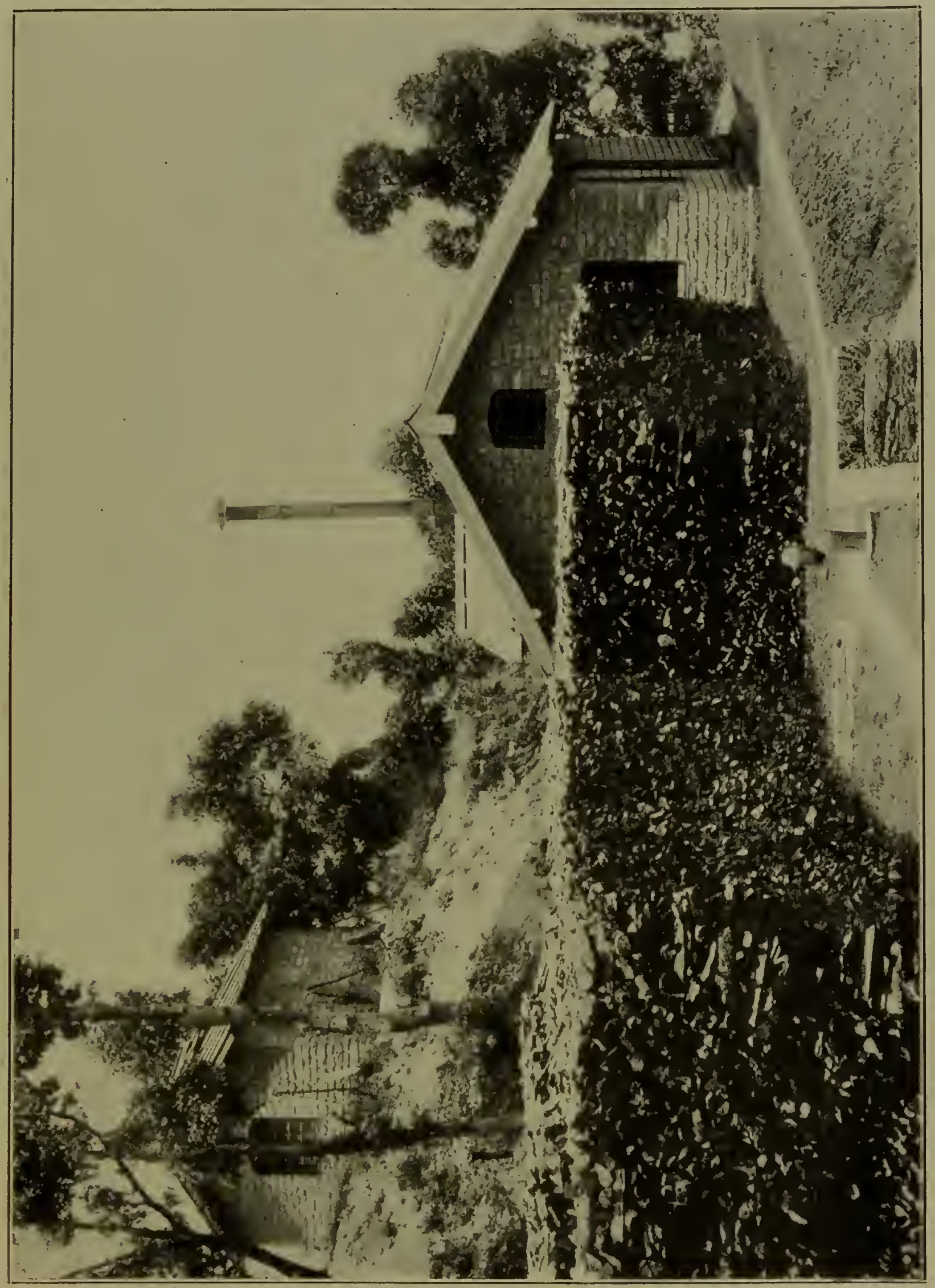

葛 



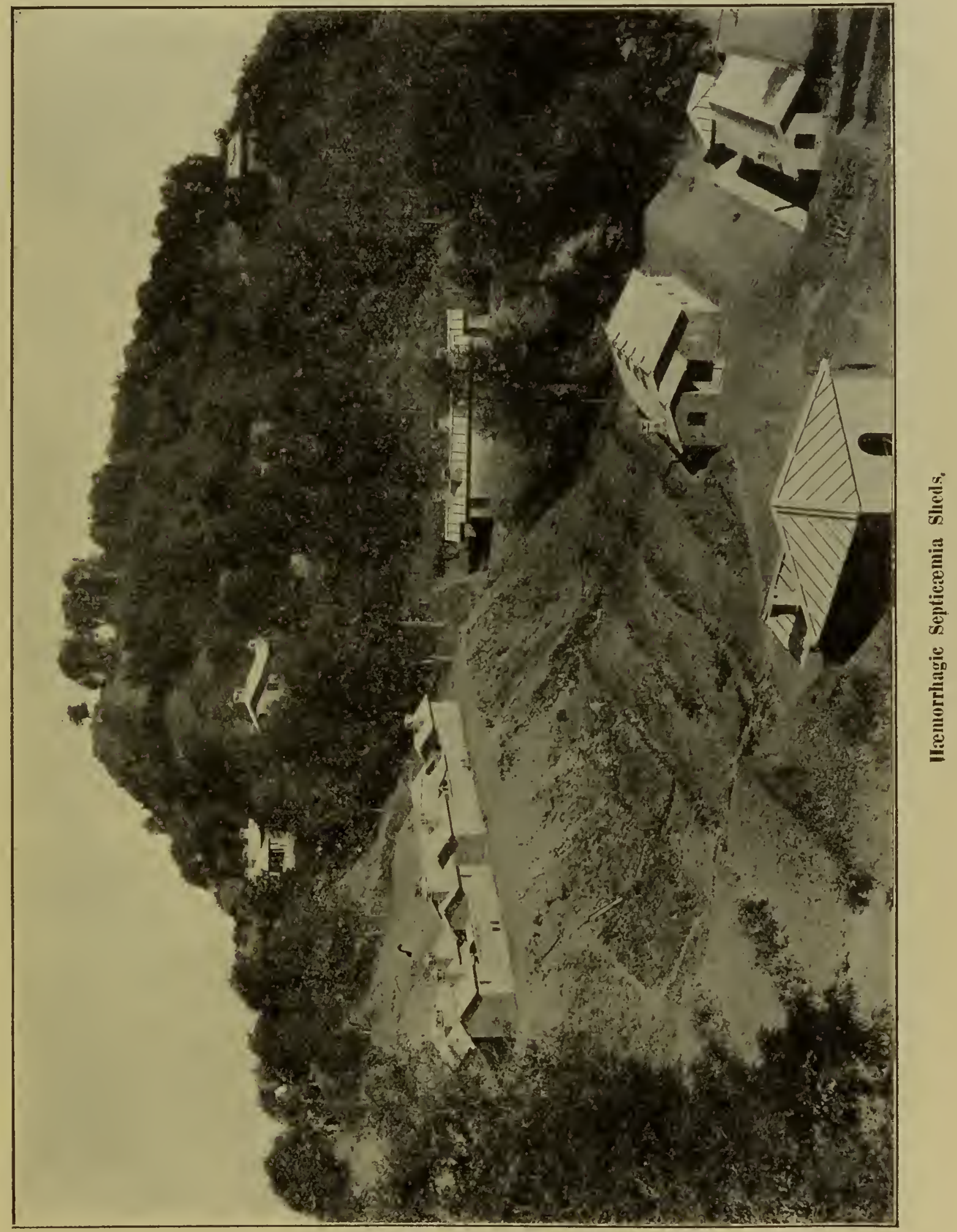





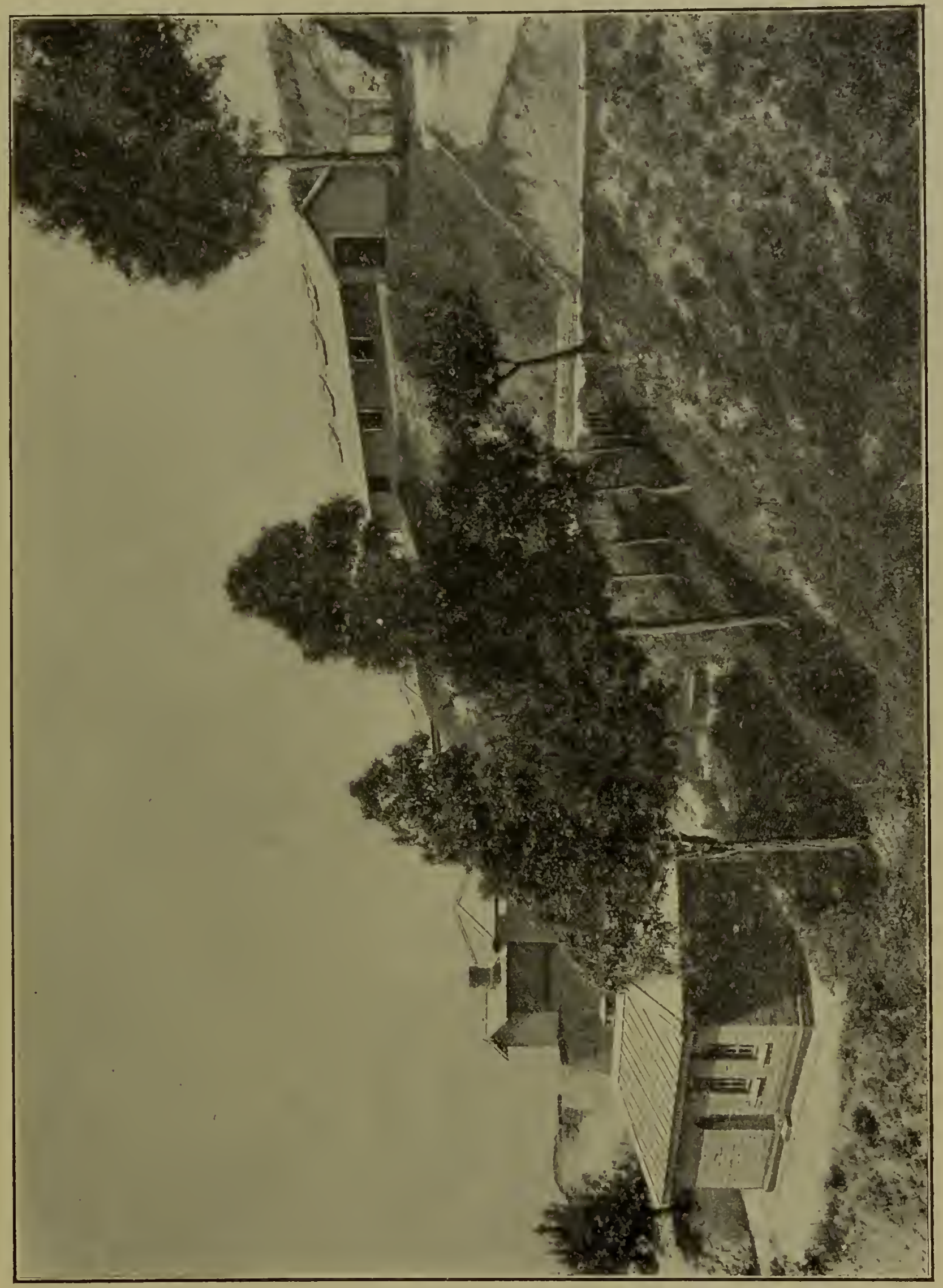

总 



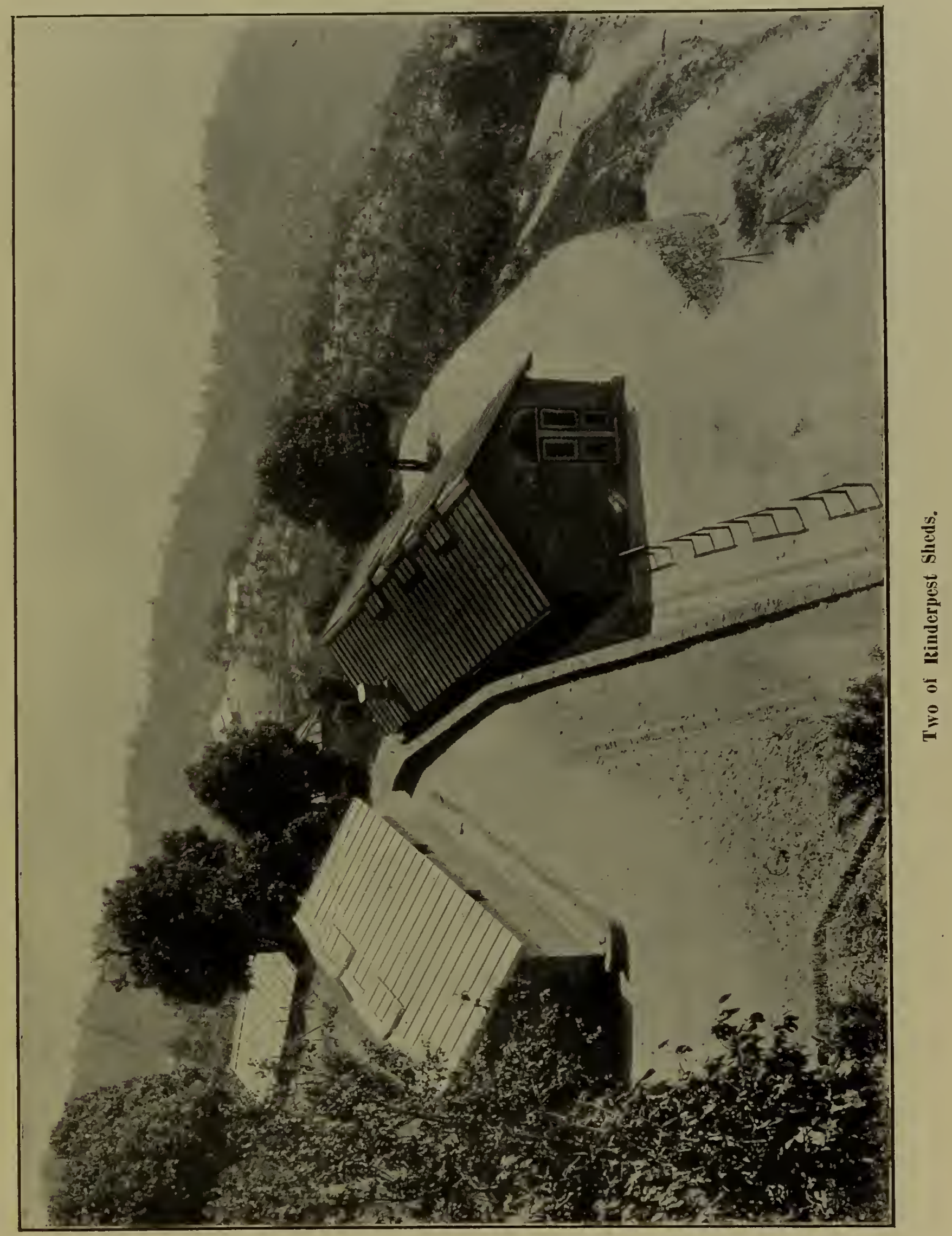




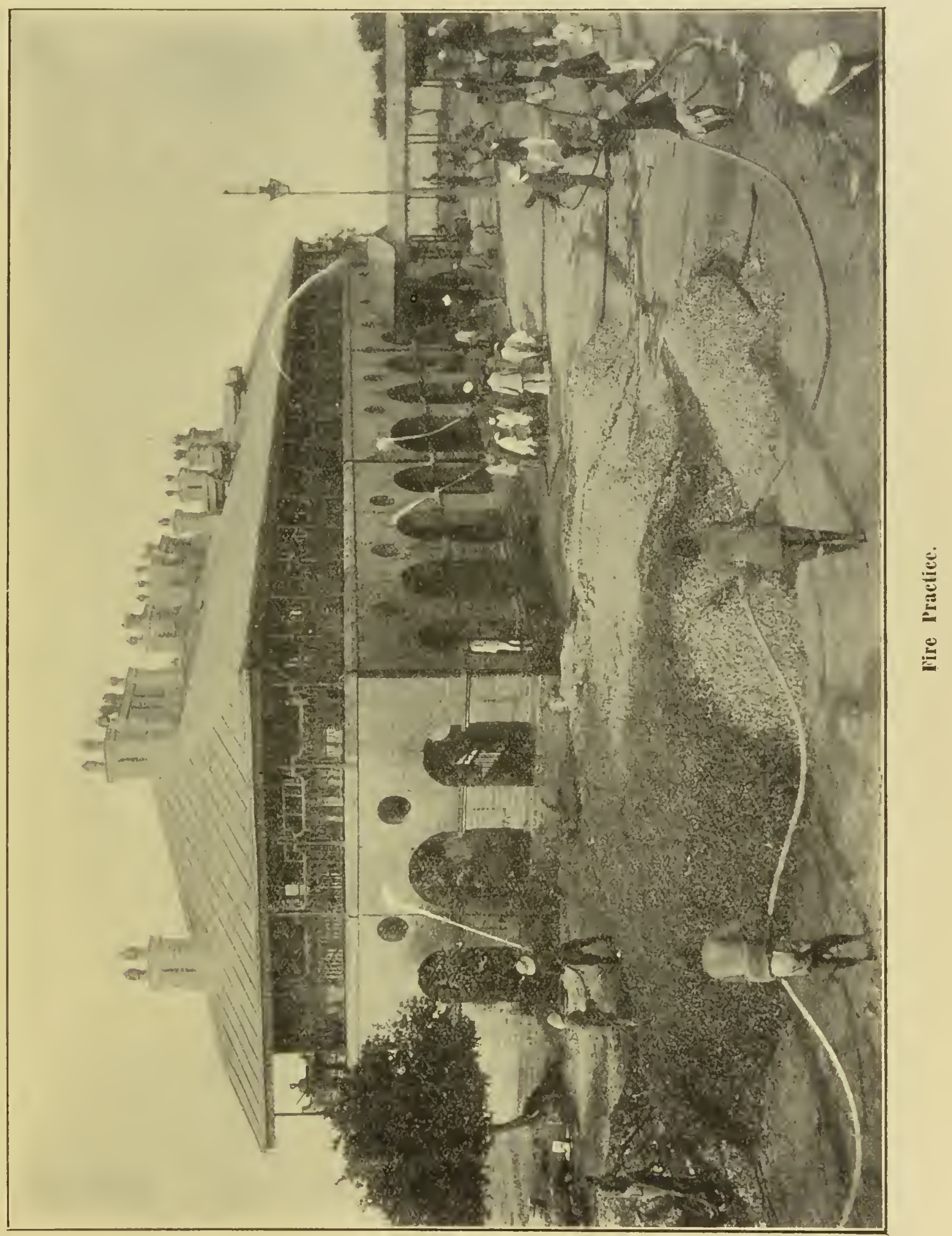




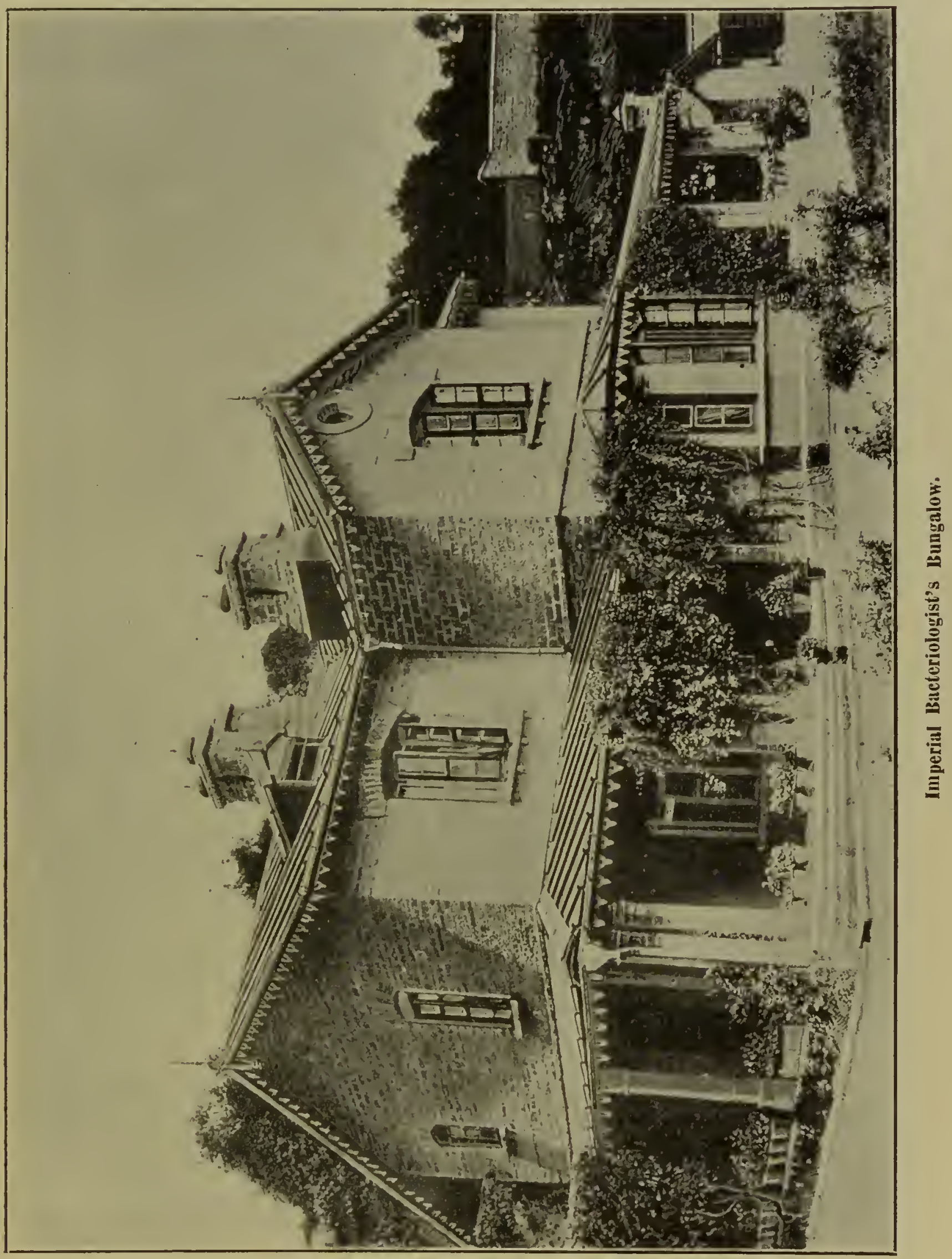





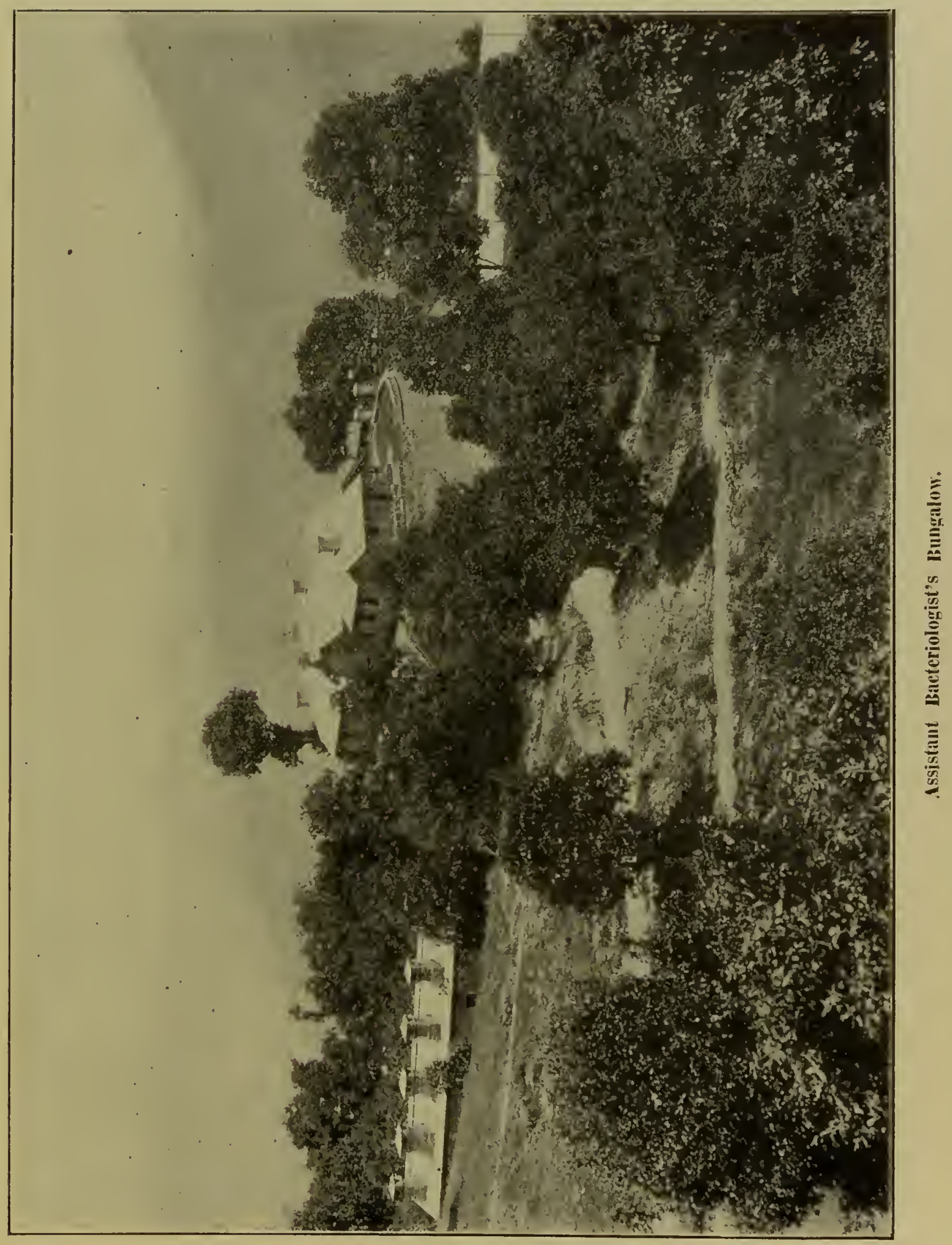





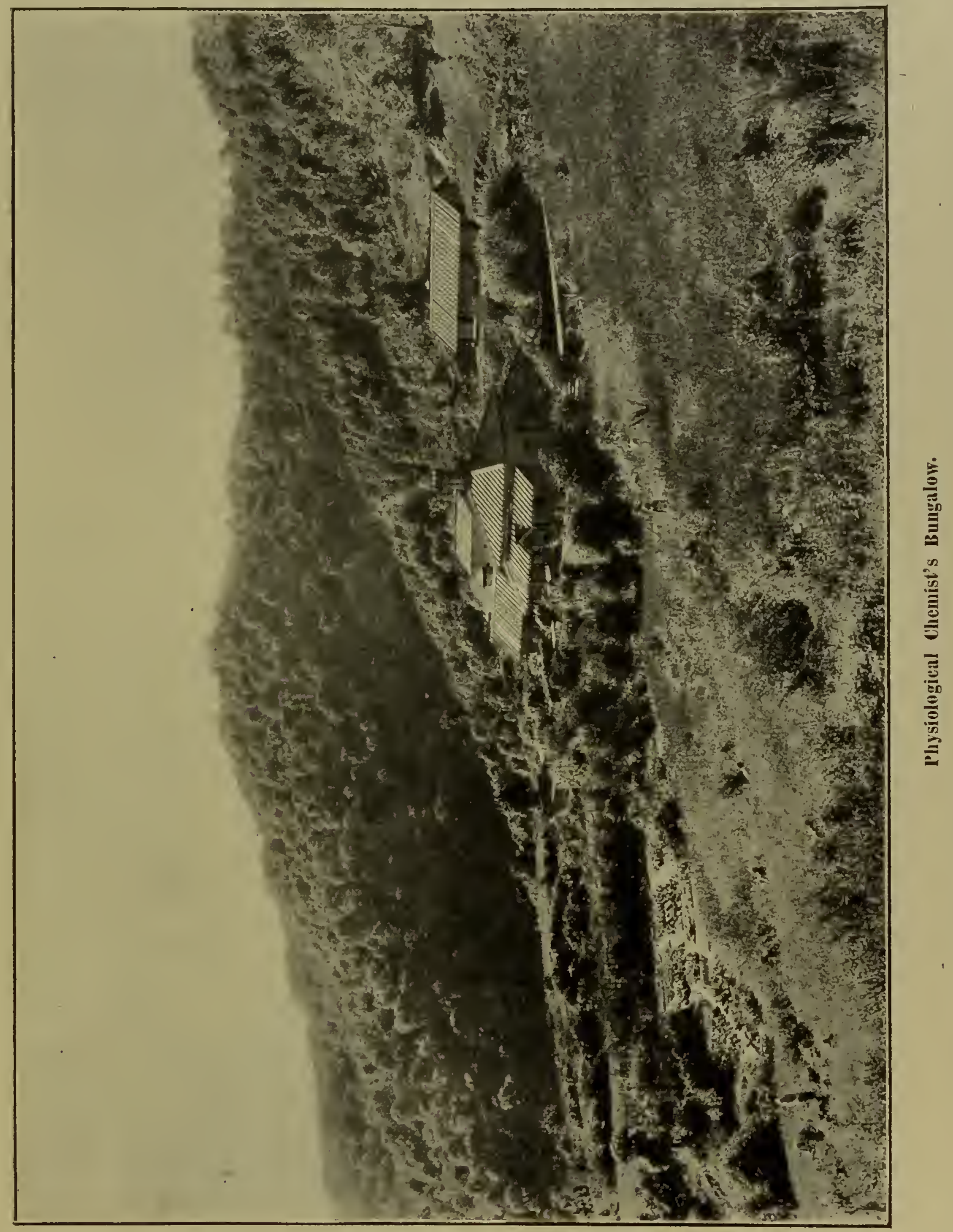





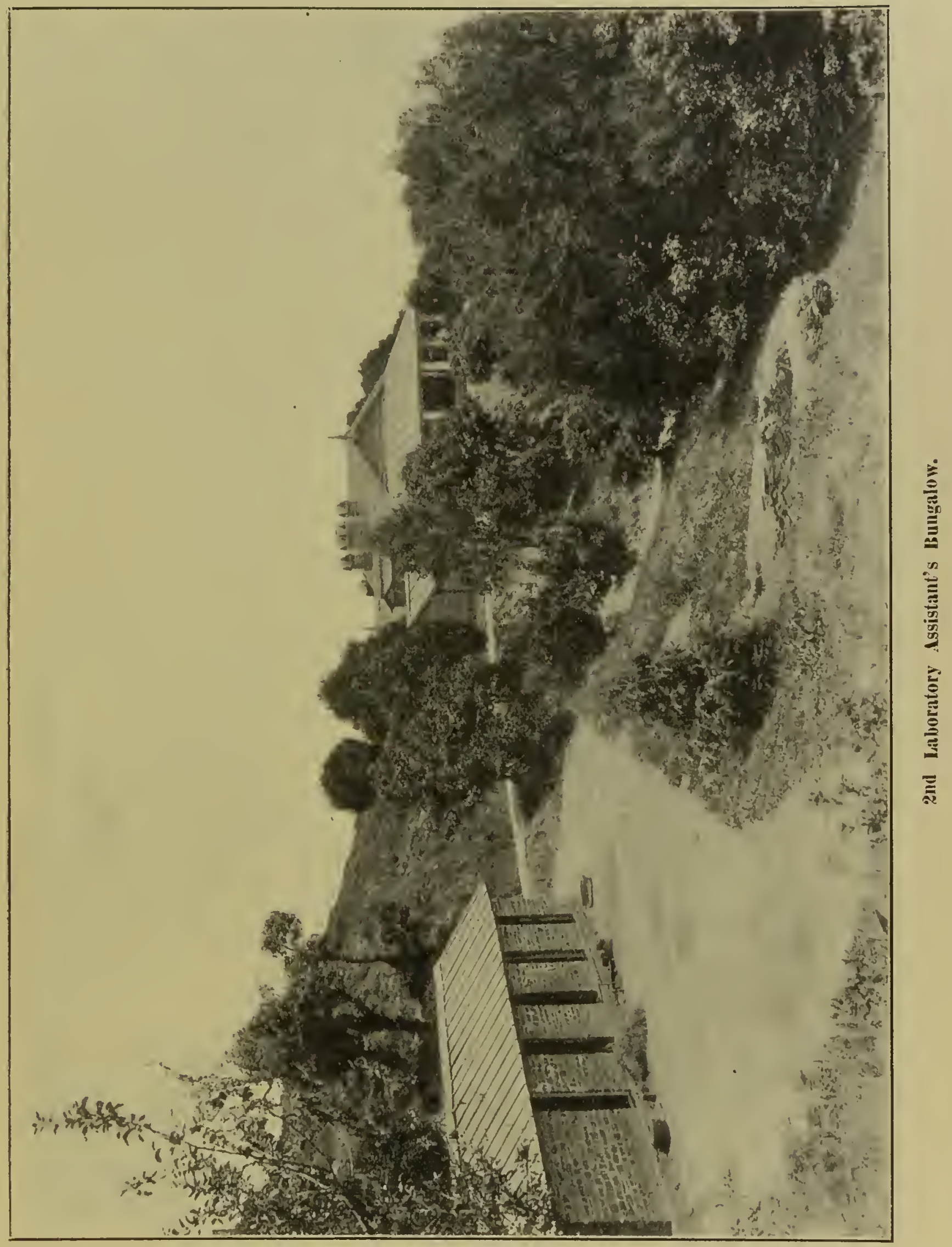





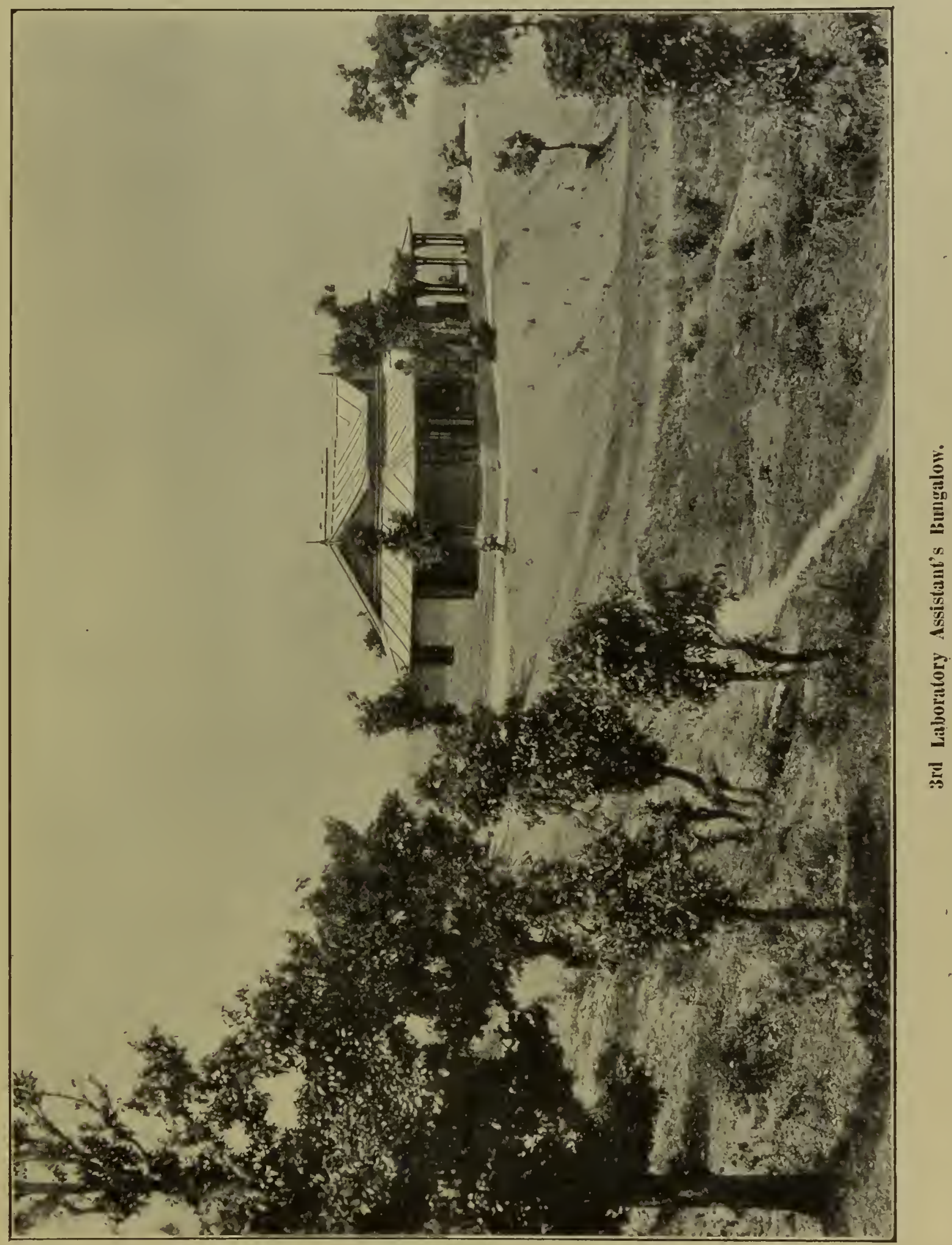





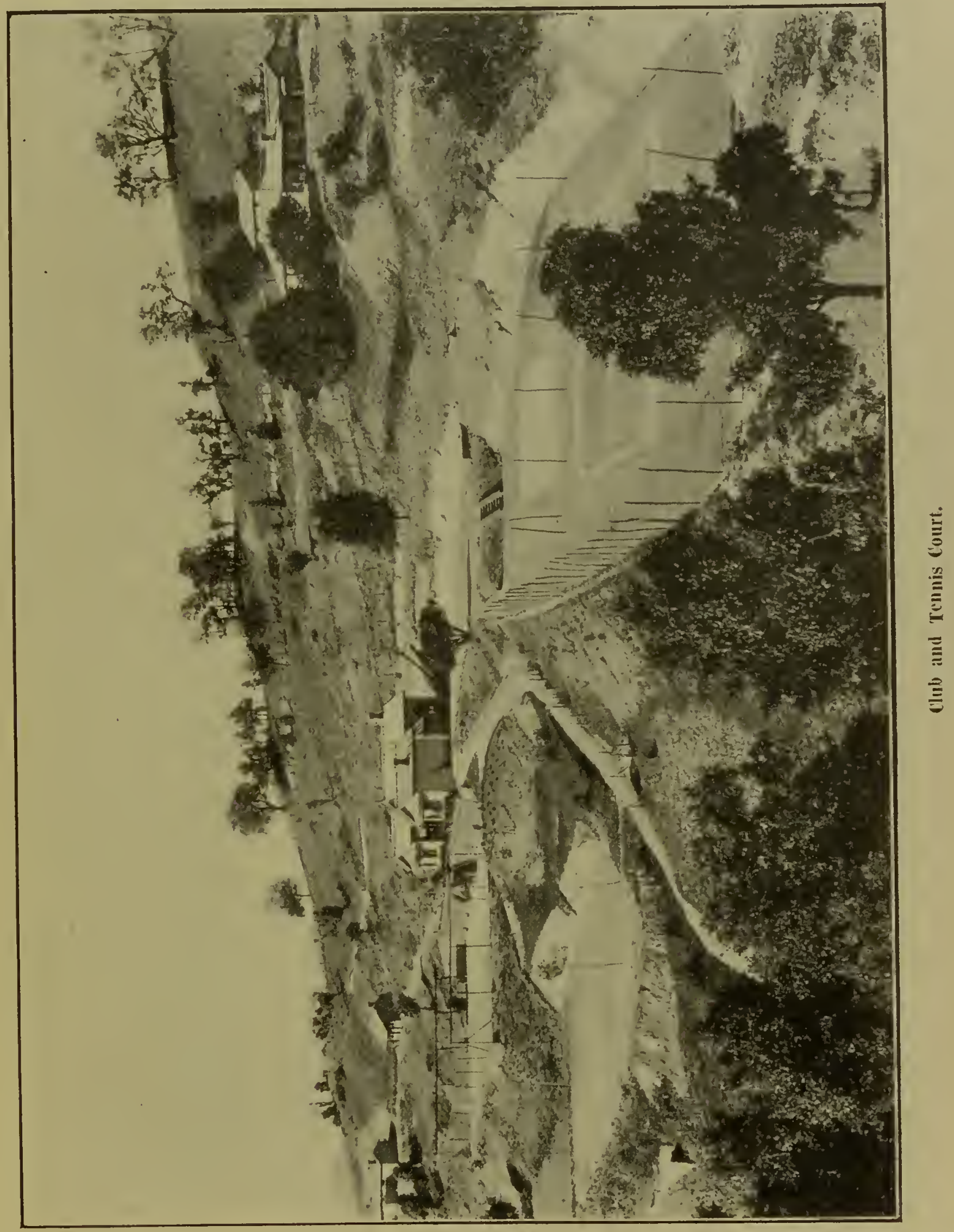





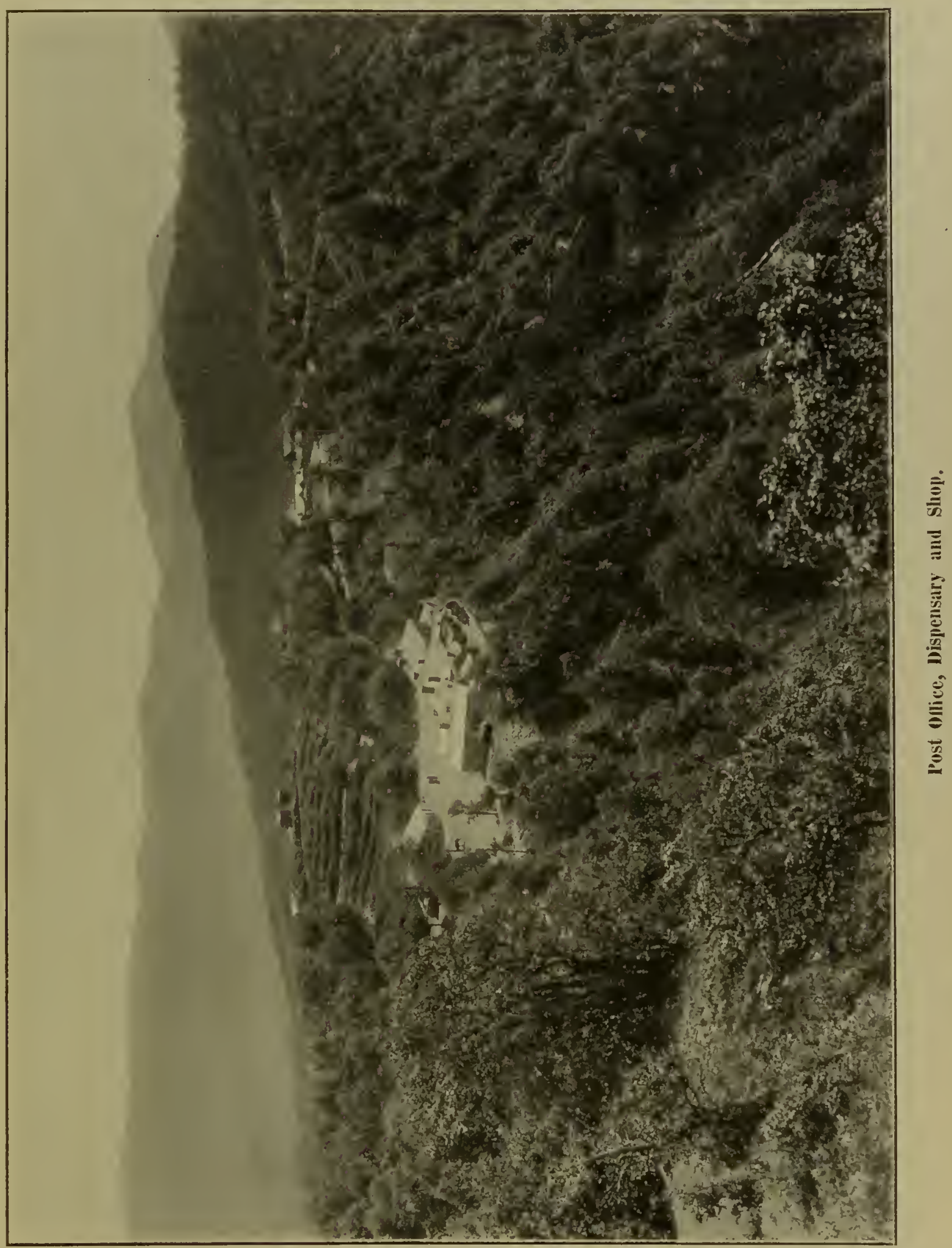





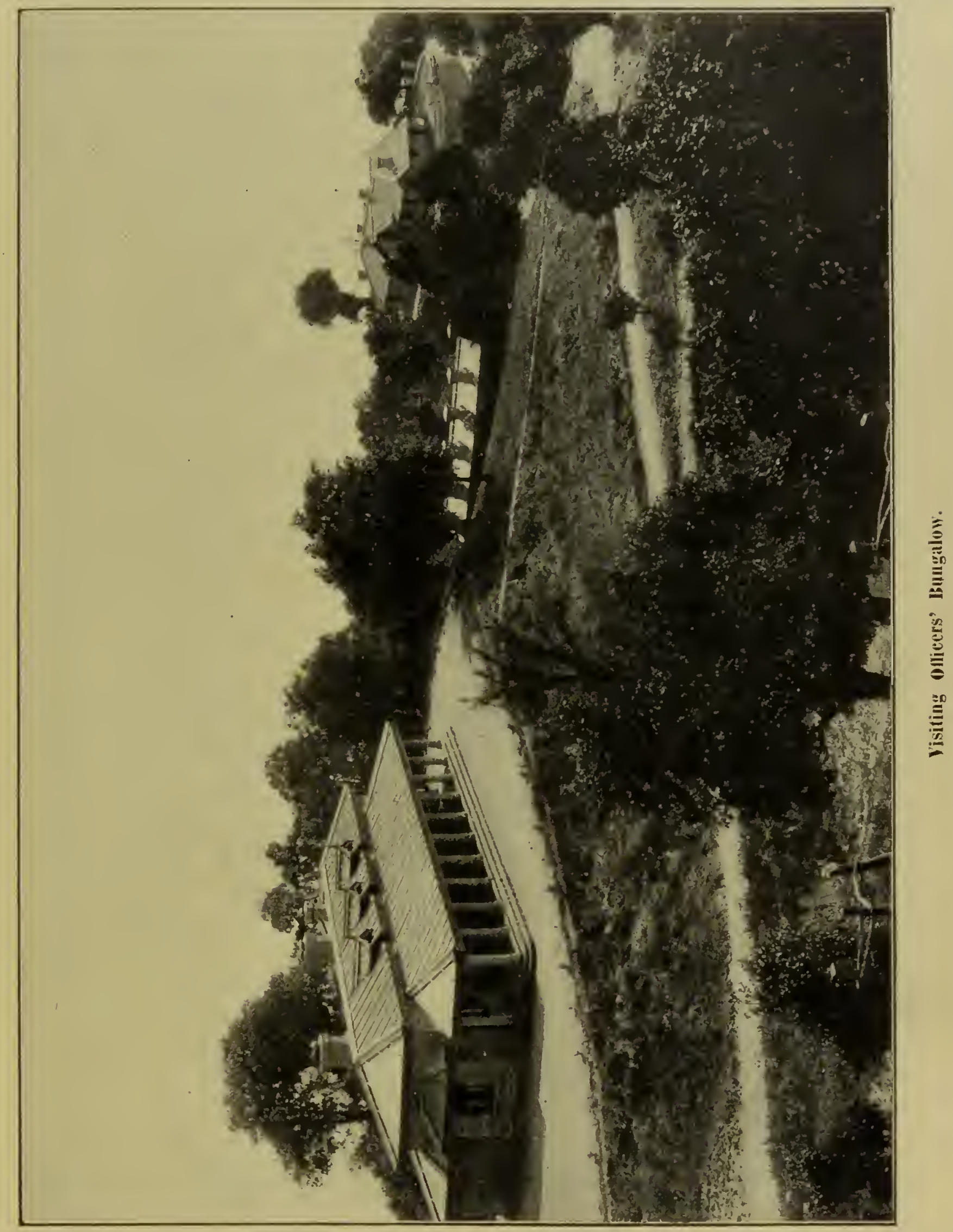





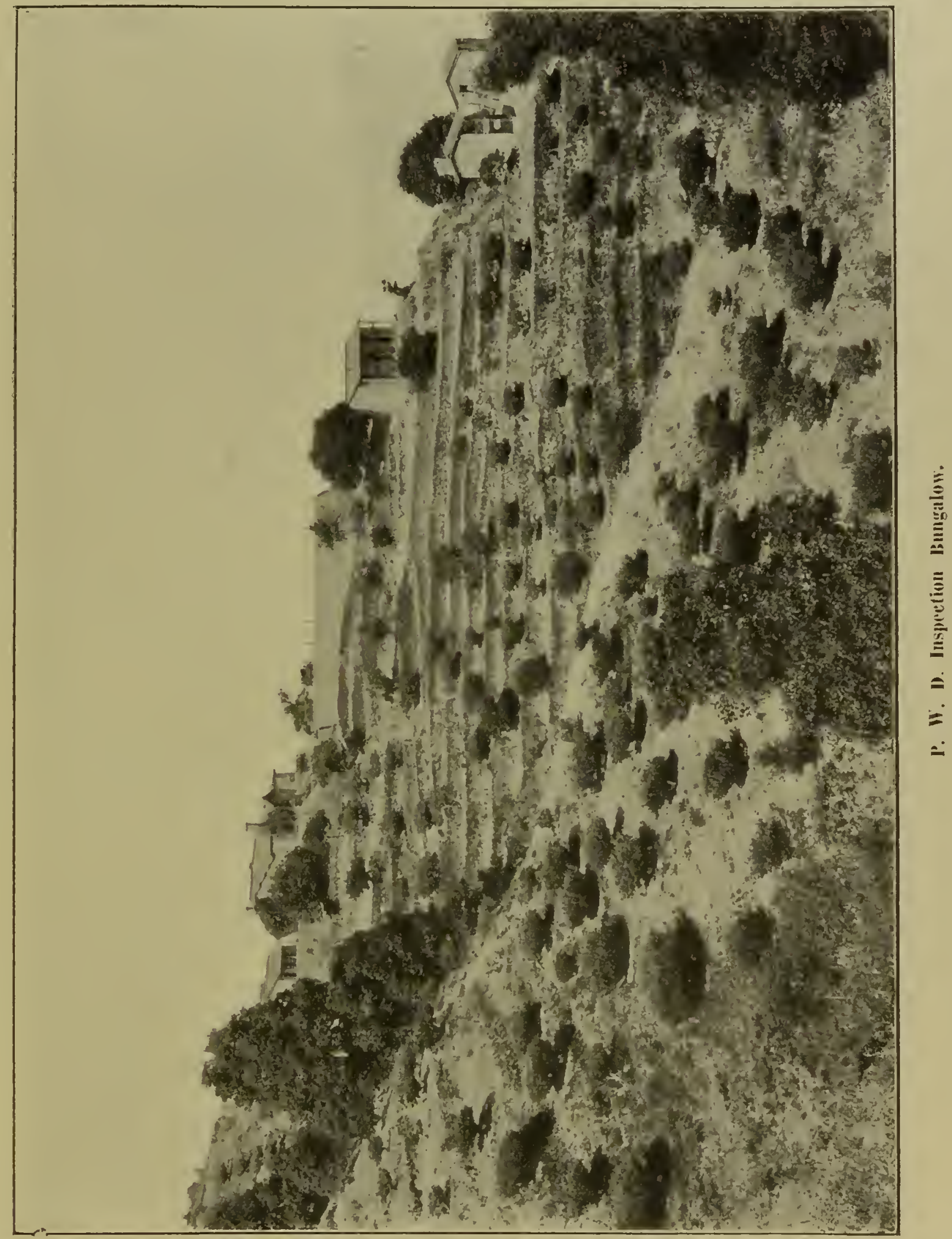





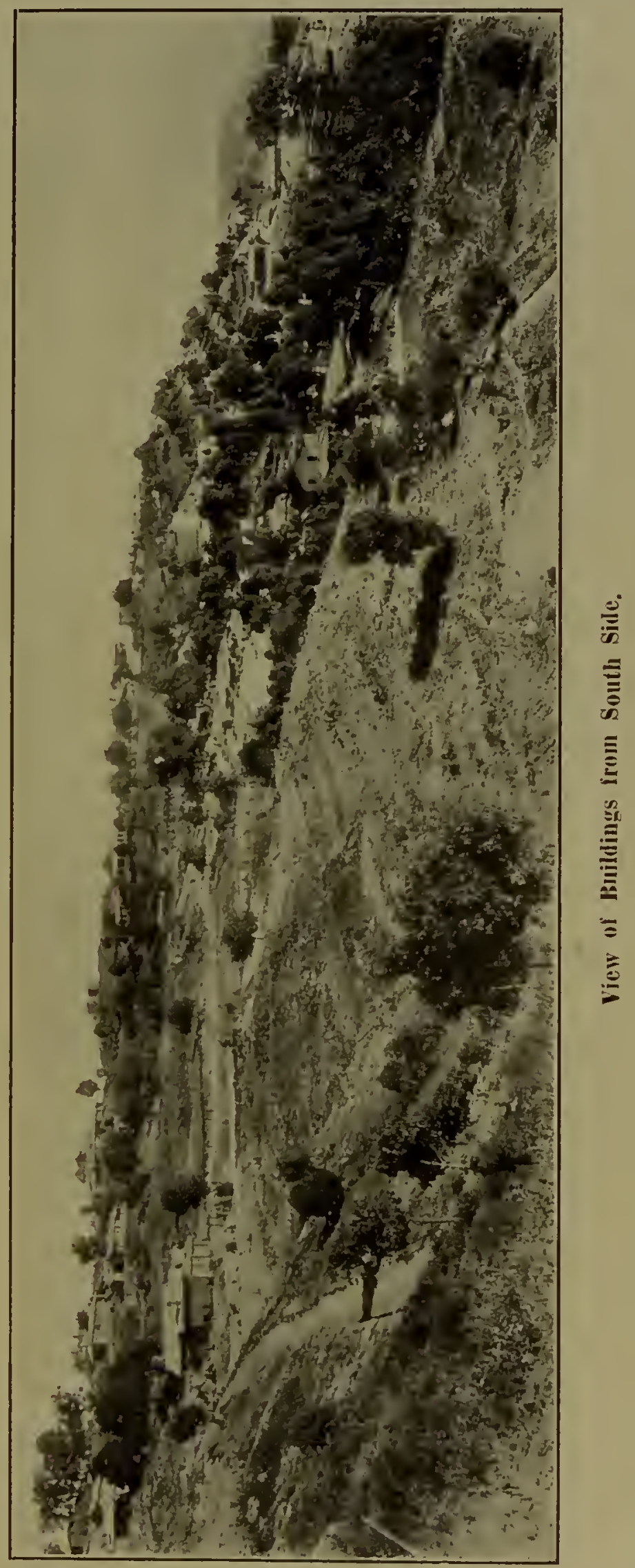





\section{CALCUTTA}

SUPERINTENDENT GOVERNMENT PRINTING, INDIA

8. HASTINGS STREET. 



